\author{
Economics Working Paper Series
}

2021/007

\title{
Import Competition, Formalization, and the Role of Contract Labor
}

\author{
Pavel Chakraborty, Rahul Singh and Vidhya Soundararajan
}

The Department of Economics

Lancaster University Management School

Lancaster LA1 4YX

UK provided that full acknowledgement is given. 


\title{
Import Competition, Formalization, and the Role of Contract Labor*
}

\author{
Pavel Chakraborty ${ }^{\dagger} \quad$ Rahul Singh ${ }^{\ddagger} \quad$ Vidhya Soundararajan $^{\S}$
}

June 2021

\begin{abstract}
Using the case of the Indian manufacturing sector and exploiting plausibly exogenous variation from Chinese imports, we provide causal evidence that higher import competition increases the share of the formal enterprise employment. We find an increase in the level of formal enterprise employment, driven by the high productivity firms, and in contrast, a fall in the informal enterprise employment. This labor reallocation is enabled by contract workers, who do not carry stringent firing costs. Our estimates imply that Chinese import competition led to an increase in the share of formal sector employment by 4.1 percentage points between 2000 and 2005 . We calculate the labor productivity gap between the formal and informal sector, adjusting for differences in prices and worker characteristics and find them to be salient in explaining the observed gap. Our preferred estimate of the productivity gap implies an increase in labor productivity by $3.19 \%$ in response to Chinese import competition.
\end{abstract}

Keywords: Formal sector employment, Contract workers, Chinese imports, Reallocation, Misallocation.

JEL Codes: F14, F16, O17, O47, F66

*We thank Aditya Bhattachaerjea, Nancy Chau, Kunal Dasgupta, Abhiroop Mukhopadhyay, K V Ramaswamy, and the seminar participants of the Midwest International Economics conference 2019 (St. Louis), 15 ${ }^{\text {th }}$ Annual Conference on Economic Growth and Development 2019 (ISI New Delhi), Delhi School of Economics Winter Meetings 2019, Indian Institute of Technology Kanpur, Indian Institute of Technology Bombay, SAMVAAD (virtual series), CAFRAL RBI, NEUDC (Dartmouth), and the First Biennial Conference on Development (Trade and Development) IGIDR, Annual Economics Conference at Ahemedabad University, Indian Statistical Institute New Delhi, SOLE's annual Meeting 2021, for comments and discussions. We thank Ananyo Brahma and Aakriti Saraswat for excellent research assistance. Vidhya Soundararajan thanks the Indian Institute of Management Bangalore for research support. Rahul Singh was the IIMB-Tata Motors Research fellow while working on this paper. All errors are our own.

${ }^{\dagger}$ Department of Economics, Management School, Lancaster University, LA1 4YX, UK; Email: p.chakraborty1@lancaster.ac.uk

¥Ahmedabad University. E-mail: rahul.singh@ahduni.edu.in

§Indian Institute of Management, Bangalore. E-mail:vidhyasrajan@iimb.ac.in 


\section{Introduction}

The presence of a large informal sector in developing countries hinders economic growth by reducing aggregate productivity due to misallocation of resources (Hsieh and Klenow, 2009). ${ }^{1}$ Any reallocation of employment towards more productive formal sector firms, therefore, can increase aggregate productivity and promote growth. ${ }^{2}$ Given that the firms in developing countries are increasingly exposed to import competition, it is important to study the role of import competition on the allocation of labor across the formal and informal sectors. Import competition can increase formal employment as unproductive informal firms exit, but can also decrease formal employment if unproductive formal firms transition to the informal sector (Dix-Carneiro et al., 2021). Not surprisingly, the empirical evidence on the effect of import competition on informality is mixed, with some studies showing null or economically small positive effects on informality (Goldberg and Pavcnik, 2003; Paz, 2014), while others showing significant positive effects on informality (DixCarneiro and Kovak, 2019).

Exploiting the meteoric rise of Chinese manufacturing imports, we provide new evidence that higher import competition from China increased the share of employment in the formal sector manufacturing enterprises in a large developing country, India. ${ }^{3}$ This was driven both by a decline in informal enterprise employment and an increase in the level of formal enterprise employment. Our findings suggest that import competition, by forcing informal firms to exit, can reallocate resources toward more productive formal firms leading to aggregate productivity gains in developing countries. An important contribution of our study is to show that trade can induce formalization by increasing competition in the domestic market, a result hitherto only observed in the context of export market access (McCaig and Pavcnik, 2018 and Costa et al., 2016).

\footnotetext{
${ }^{1} \mathrm{~A}$ large share of informal sector also constrains growth by lowering the tax base and hindering fiscal capacity (Besley and Persson, 2013; Levy, 2010)

${ }^{2} \mathrm{~A}$ variegated set of policy options have been considered to promote formalization and the growth of small enterprises, including the lowering of registration costs or taxes for formal firms, providing capital grants to small firms, and the careful dismantling of size-based policies to incentivise growth (De Mel et al., 2013; McKenzie, 2017; Rocha et al., 2018).

${ }^{3} \mathrm{~A}$ large share of employment in India is concentrated in the informal sector. In 2005, the share of informal workers in the manufacturing sector employment was approximately 80\%(Asturias et al., 2019)
} 
Studying the impact of import competition on labor reallocation between the informal and formal sector enterprises presents several challenges. First, comprehensive data on informal enterprises are usually not available. India is the only country we are aware of where nationally representative surveys of informal enterprises covering both urban and rural areas, and using non-household sampling units are available. ${ }^{4}$ We exploit the availability of these enterprise data, and complement them with formal sector firm level data for the years 2000-2001 and 2005-2006, to study the allocation of employment between these sectors in this period. We categorize firms as formal or informal using a size (employment) based objective criterion set by the Factories Act $1948 .^{5}$

A second challenge lies in identifying the effects of import competition on employment, which is often riddled with simultaneity concerns related to unobserved demand and technology shocks that affect both imports and employment. We exploit the differential exposure of industries in India to Chinese imports to study the relationship between import competition and formal share of employment.The increase in Chinese imports are plausibly exogenous because they are primarily driven by the increase in manufacturing productivity in China due to its own internal reforms (Acemoglu et al., 2016; Autor et al., 2013). ${ }^{6}$ The share of Chinese imports to overall imports to India stood at a remarkable 18 percent in 2007. While Chinese import share to India rose by over 16 times between 1998-2007, imports from other low- and middle, and high-income countries to India only doubled. To address any remaining endogeneity concerns, we employ an instrumental variable strategy that uses Chinese imports to a set of Latin American countries as an instrument for Chinese imports into India (following Acemoglu et al., 2016). ${ }^{7}$ We control for alternative trade

\footnotetext{
${ }^{4}$ Brazil conducts informal enterprise surveys every five years, but these are restricted to urban areas. The informal sector surveys of Mexico (ENAMIN) were conducted only in urban areas until 2005. Further, both ENAMIN and Cameron's Employment and Informal Sector Surveys use household as the sampling unit to survey details on household-owned enterprises. On the contrary, India's unorganized sector surveys cover all regions (except some extremely remote areas), and use the Economic Census of India that provides a comprehensive coverage of units undertaking any economic activity, as the sampling frame.

${ }^{5}$ Nataraj (2011) and McCaig and Pavcnik (2018) similarly use an enterprise-based definition of informality.

${ }^{6}$ Among other things, these internal reforms enabled the setting up of special economic zones (Alder et al., 2013), facilitated technology transfers through foreign direct investments (Autor et al., 2016) and multinational activity (Naughton, 2006), and promoted the mass migration of workers from rural to urban areas (Chen et al., 2010). Further, China's accession to the World Trade Organization in 2001 provided an additional boost to its exports (Branstetter and Lardy, 2006).

${ }^{7}$ The Latin American countries that we use for constructing the instrumental variable are Argentina,
} 
channels and a rich set of fixed effects to control for unobservables.

A final challenge lies in quantifying the aggregate productivity changes due to reallocation of labor across the two sectors. A well documented issue with calculating labor productivity gap between the sectors using revenue data is that it captures differences in prices, due to markup and demand shocks, in addition to underlying productivity differences across the two sectors (McCaig and Pavcnik, 2018). Since formal sector firms, on average, charge higher prices compared to the informal sector, the observed productivity gap between the two sectors is likely to be inflated. Another contribution of our study is that we exploit the availability of unique data on physical production and sales for all firm-products in the firm level surveys for both formal and informal sectors to adjust the observed productivity gap for price differences across the sectors.

Our results imply that between 2000 and 2005, Chinese import competition led to an increase in formal share of employment by 4.1 percentage points. This increase in formal share of employment was driven by an increase in formal sector employment while the informal sector contracted significantly resulting in net employment losses in the industry. We evaluate the potential gains in aggregate labor productivity from this trade-induced shift of workers across the two sectors employing standard development accounting methods (Caselli, 2005). Our preferred estimate of labor productivity gap is 2.18, after adjusting for differences in prices, human capital, hours worked between the formal and informal sectors. Our calculations suggest that ignoring price differences leads to overestimation of productivity gap by $70 \%$. Using this measure of labor productivity gap, we estimate that Chinese import competition led to an increase in aggregate labor productivity by $3.19 \%$ relative to the baseline labor productivity.

This increase in formal sector employment in response to import competition is driven by contract labor. Unlike the firm's regular workers, contract workers are employed on fixed term contracts through third party intermediaries and do not carry firing costs. ${ }^{8}$

Brazil, Chile, Colombia, Costa Rica, Mexico, Paraguay, Peru, Uruguay, and Venezuela. We choose these countries as they are not major trade partners of India and thus, the possibility of alternative trade channels contaminating our estimates is diminished.

${ }^{8}$ In India, the Industrial Disputes Act, 1947, imposes considerable firing costs for regular workers directly employed by large formal firms (Besley and Burgess, 2004). 
We find that Chinese import competition led to an overall increase in contract labor by 10.1\%. Overall, these results indicate that the institution of contract labor enable the smooth reallocation of workers between the informal and formal sectors. These results are consistent with studies that show that stringent firing costs imposed by Employment Protection Laws (EPL) limit employment adjustment and hamper the worker reallocation (Boedo and Mukoyama, 2012; Hopenhayn and Rogerson, 1993; Kambourov, 2009), and that contract or temporary workers enable smoother adjustment of workforce even in the presence of strict firing laws, as documented in India (Chaurey, 2015; Saha et al., 2013) and the United States (Autor, 2003). These results on contract labor are further consistent with Bertrand et al. (2015) that demonstrate the role of contract labor in the growth of the large formal sector manufacturing firms in India.

Overall, the results indicate that workers reallocated from the informal sector are predominantly absorbed as contract workers in the formal sector. Our estimates suggest that reallocated workers experience a gain in wages of $0.3 \%$ relative to the baseline wage. While these wage gains are modest, the reallocated workers also stand to gain legal protection which is absent in informal enterprises. While informal enterprise workers do not enjoy any legal protection, contract workers are covered under the Contract Labor Act 1970 that provides several welfare amenities such as the minimum wage, timely wage payment, and safety and amenities at workplace.

Institutions that increase the costs of operating in the formal sector lead to misallocation in the form of a large informal sector (Boedo and Mukoyama, 2012; Hsieh and Klenow, 2009). We would expect import competition led reallocation to be more pronounced in contexts where misallocation and informality is already high to begin with. In India, informality is higher in states with stringent labor firing regulations and stronger union presence. Indeed, we find that the overall increase in formal share of employment as a result of Chinese import competition is primarily driven by states with more stringent Employment Protection Laws (based on the classification in Besley and Burgess (2004)) and states with high level of unionization of workers. We also observe that formalization transition in these states are, in turn, driven by contract labor. Our findings suggest that 
Chinese import competition could reduce misallocation through the reallocation of labor from the informal to the formal sector, leading to aggregate productivity gains.

Our study contributes to the literature examining the relationship between trade and informality. Our study relates to Dix-Carneiro et al. (2021) who study the role of trade liberalization in a structural general equilibrium model through counterfactual simulations and find that reduction in trade costs results in the exit of informal firms and a large decline in informal employment in the import competing sector in Brazil. Our findings complement these results and provide reduced form causal evidence that Chinese import competition leads to an increase in the formal share of employment and aggregate productivity gains in the import competing sector. Our study is also related to McCaig and Pavcnik (2018), who find that export market access increases aggregate productivity by increasing the formal share in employment. Complementing their findings, we provide the first empirical evidence that import competition led formalization also leads to productivity gains from trade.

Our work also relates to empirical papers studying the effect of tariff liberalization episodes on informality. Dix-Carneiro and Kovak (2019) and Paz (2014) study tariff liberalization in Brazil and find that tariff reductions lead to increase in informality. Goldberg and Pavcnik (2003) find that tariff liberalization had a significant positive impact on informality in Colombia in the period preceding labor market reforms, while report no effects on informality in Brazil. Cisneros-Acevedo (2019) finds that hiring of informal workers by registered employers increased due to tariff liberalization in Peru. In contrast to these findings, our results suggest that import competition reduces the share of employment in the informal sector. Our focus on an enterprise-based definition of informality, combined with detailed firm level data on formal and informal sector firms enables us to study reallocation of workers across firms with differing underlying productivities and quantify the ensuing productivity gains.

We also contribute to the growing literature on the effects of Chinese import competition on employment (Acemoglu et al., 2016; Autor et al., 2013, 2014; Bloom et al., 2016; Utar and Ruiz, 2013). ${ }^{9}$ These studies document a significant negative impact of Chinese imports on

\footnotetext{
${ }^{9}$ Mansour et al. (2020) find that Chinese import competition leads to adverse employment consequences
} 
manufacturing employment. Consistent with these findings, we also document short term employment losses in industries more exposed to import competition.

The rest of the paper is organized as follows. Section 2 provides a conceptual framework. Section 3 discusses the data sources. Section 4 presents the empirical strategy. Section 5 presents and discusses the results and the robustness checks. Section 6 documents the increase in aggregate productivity due to reallocation from informal to formal sector. Section 7 concludes.

\section{Conceptual Framework}

In this section, we briefly layout the potential mechanisms linking import competition to the allocation of labor across the formal and informal sector in a developing country. Import competition can lead to increase in formal share of employment due to exit of informal firms (extensive margin) as well as due to increase in the employment ratio of formal and informal sector firms (intensive margin).

An increase in imports to an industry reduces demand for firms, and this would disproportionately reduce the profits of firms with higher marginal costs. Informal firms, on average, have substantially lower productivity compared to formal sector firms (McCaig and Pavcnik, 2018), either due to differences in underlying productivity (Melitz, 2003) or managerial ability (Lucas Jr, 1978). Import competition would induce some low productivity formal firms to transition to the informal sector, but it would also force some unproductive informal firms to exit the industry as they are unable to earn enough profits to stay in the market (Dix-Carneiro et al., 2021). Thus, the overall effect of import competition on informal employment can be positive or negative depending on the channel that dominates. In a counterfactual analysis on the Brazilian economy, Dix-Carneiro et al. (2021) find that the extensive margin of exit of informal firms dominates and a reduction in trade costs results in a significant lowering of informal share of employment in the import competing sector. It is important to note that we have implicitly assumed that the informal sector directly for women workers in Peru. 
competes with Chinese imports. In India, there is abundant anecdotal evidence that the informal sector directly competes with Chinese imports and it is negatively impacted by Chinese import competition. ${ }^{10}$

In models with heterogeneous firms, monopolistic competition, and endogenous markup, as in (Melitz, 2018), import competition can also lead to intensive margin reallocation toward the more productive formal firms. ${ }^{11}$ High productivity firms, who also charge higher markup, will reduce markup and hence prices as the price elasticity of demand increases in response to increase in import competition. This leads to reallocation of output and labor towards more productive formal firms.

Further, increased import competition can induce high productivity firms to increase investments and employment (escape competition effect) while low productivity firms shrink and are discouraged from investing (Schumpeterian effect) (Aghion et al., 2005). ${ }^{12}$ Import competition could also induce formal firms to increase the demand for contract workers to counter the bargaining power of permanent workers (Saha et al., 2013). This increase in demand for workers by high productivity formal firms would increase the opportunity cost of workers in the informal sector. If formal and informal firms compete in the labor market, this would further reinforce the reallocation of workers towards the more productive formal firms.

Our discussion above linking import competition to formal share of employment has abstracted from mobility frictions that may restrict the movement of workers from informal to the formal sector and would dampen the reallocation process. If these frictions are salient, it would frustrate any attempt to empirically identify the reallocation effect of import competition. Taken together, these mechanisms highlight the complex relationship between import competition and labor allocation across the formal and informal sectors. Whether import competition leads to an increase or decrease in formal share of employment

\footnotetext{
${ }^{10}$ See, for example, ASSOCHAM (2013a,b); Khan (2014); Roy (2013); Sathyanarayana (2014).

${ }^{11}$ There is empirical evidence that markups vary across firms within industries in India. De Loecker et al. (2016) document considerable differences in markup across firms within industries in the manufacturing sector in India.

${ }^{12}$ Gutiérrez and Philippon (2017), studying US firms, find that Chinese import competition leads to increased investments and employment in firms with high market share while it reduces investments and employment in laggard firms. Bloom et al. (2016) study European manufacturing firms and find that Chinese import competition leads to reallocation of workers toward technologically more advanced firms.
} 
is ultimately an empirical question.

\section{Data Sources and Measurement of Informality}

\subsection{Data Sources}

Our primary source of data on informal firms is the quinquennial cross-sectional unorganized sector enterprise (NSS) surveys conducted by the National Sample Survey Organization (NSSO). For the formal sector, we use data for manufacturing plants from the Annual Survey of Industries (ASI), conducted by the Central Statistical Office (CSO), Government of India. ${ }^{13}$ We use the ASI data in 2000-2001 and 2005-2006 to match with the years the NSSO unorganized sector survey data are available. Henceforth, we refer to this combined dataset as ASI-NSS. We observe information on the number of employees in both the NSS and ASI establishment surveys. In addition, the ASI also reports information separately on regular employment and contract employment. ${ }^{14}$

Further, both the NSS and ASI surveys are unique in that they capture detailed information on physical production, units of measure, and sales for disaggregated product lines produced by each firm. ${ }^{15}$ We also use the unit level panel ASI data with firm identifiers from 1998-1999 to 2007-2008 to study outcomes within the formal sector firms over time. ${ }^{16}$

Our primary source of worker level data is the Employment-Unemployment survey (EUS henceforth) conducted by the NSSO. This is a quinquennial cross-section survey and we utilize data for two years, namely, 1999-2000 and 2004-2005. The survey reports data on worker characteristics such as age, gender, education, martial status, residence location, religion, and social group, and employer characteristics, such as, firm size and usage of electricity.

\footnotetext{
${ }^{13}$ These surveys use the Economic Census-a complete enumeration of all entrepreneurial units in India-as the sampling frame.

${ }^{14}$ Another important micro-level dataset on Indian firms is PROWESSS, which is published by the Centre for Monitoring Indian Economy (CMIE). However, unlike the ASI, PROWESS does not collect data on contract workers and therefore may not be suitable to explore the changes in labor market.

${ }^{15}$ The product lines are classified according to the Standard Industrial Commodity Classification (ASICC) classification.

${ }^{16} 1998$ is the first year for which ASI is available with an establishment identifier.
} 
Our primary source of trade data at the industry level (NIC) is sourced from the UNCOMTRADE database. ${ }^{17}$ From this database, we compiled data on Chinese imports to India, and to a set of low- and middle-, and high-income countries. We also compiled total imports to India from low- and middle-, and high-income (other than China and the IV countries), and India's export share to countries in the instrumental variable list.

To construct the import competition measure (described in Section 3), we also require the baseline production data in India. For this, we used both formal sector output from the ASI in the year 1994, and informal sector output from the survey of unorganized manufacturing enterprises conducted by NSSO in the year 1995. We use data on input and output tariffs from Ahsan and Mitra (2014) for the years between 1998 and 2003, and from Chakraborty and Raveh (2018) for the years between 2004 and 2007.

We use data on labor institutions from two separate sources. First, we use a state level measure of strength of regulations related to unions from a survey conducted by Dougherty (2009). This measure captures state level differences in regulations related to different aspects of union representation, namely, labor law reforms relating to restrictions on the minimum number of workers in an union, recognition of unions as bargaining agents, provisions for union formation in an enterprise, rules related to strikes, and code of conduct between employers and unions. Second, we use the state level measure of labour regulation by Besley and Burgess (2004), which reflects the state level differences in stringency in the firing of regular workers under Industrial Disputes Act, 1947 (IDA), the key employment protection legislation in the Indian context.

\subsection{Measuring Informality}

India is one of the few countries to comprehensively collect periodic data on both formal and informal sector employment through representative surveys of enterprises as well as workers. Informality in India is closely linked to firm size and the government agencies classify firms as formal/informal based on Factories Act, 1948. As per the Factories Act,

\footnotetext{
${ }^{17}$ Industries are classified as per the National Industries Classification (NIC) in both the EUS as well as USE-ASI surveys.
} 
1948, any factory using power and employing 10 or more workers, and if not using power and employing 20 or more workers is deemed to be registered in the formal sector.

We use enterprise level ASI-NSS data to measure formal share of employment in each industry. The NSS and the ASI surveys are nationally representative surveys of unorganized and formal sector enterprises, respectively. This classification of formal and informal is made by the government based on firm-size and registration status, and accurately reflects the formal-informal composition in the economy. We aggregate employment from ASI-NSS at the state-industry and at the industry level, and define worker-share in the formal sector in each aggregated unit as the share of workers in the ASI to total number of workers in all firms in that unit. We also use the information on workers' employer details from the EUS, such as the number of workers and the use of electricity, to classify workers as formal and informal. ${ }^{18}$

Table 1 reports the summary statistics for worker characteristics from the EUS in Panel A and firm characteristics from ASI-NSS in Panel B. Formal workers (columns 1-3) are on average better educated, are more likely to work in urban areas, and are less likely to be females and from the disadvantages social groups and minorities, as compared to informal workers (columns 4-6). Formal firms (columns 1-3) on average have much higher sales, employ more workers, and pay much higher wages compared to informal firms (columns $4-6)$.

\section{Empirical Approach and Identification}

\subsection{Chinese Import Competition}

The steep rise in Chinese imports through the 1990s and 2000s were primarily driven by China's internal reforms leading to productivity gains, and China's accession to the WTO

\footnotetext{
${ }^{18}$ Since some factories below these employment thresholds are also registered, we reclassify workers employed in such enterprises as formal sector workers. We utilize responses on a firms' registration status, as reported by the workers, to do this reclassification. Specifically, we consider a firm below the sizethreshold to be a formal enterprise if the firm is a state-owned factory, a public/private limited company, or a cooperative. A total of 516 workers get reclassified to the formal sector, which forms about $1 \%$ of the main sample. Not surprisingly, our results are qualitatively similar without this reclassification and excluding these workers from the estimation sample.
} 
in 2001. Our main identification strategy relies on exploiting across industry variation in exposure to Chinese imports to study their effect on share of employment in formal firms. Towards this end, we obtain a measure of Chinese import penetration in an industry $j$ at time $t$, given by:

$$
I M P_{j t}^{C h i n a}=\frac{M_{j t}^{C h i n a}}{\left(Y_{j, 94}+M_{j, 94}-X_{j, 94}\right)}
$$

where $M_{j t}^{\text {China }}$ is the total imports of Chinese goods in industry $j$ at time $t ; Y_{j, 94}, M_{j, 94}$ and $X_{j, 94}$ refer to production, total imports, and total exports for industry $j$ in India in 1994. By normalizing Chinese imports to India over absorption (domestic production plus imports less exports) before the start of our study period, our measure captures the differential increase in Chinese imports across industries based on the initial size of an industry in the domestic market.

There are, however, several reasons why an ordinary least squares regression of employment on import competition could produce biased estimates. For example, industry level demand shocks that drive Chinese imports could also simultaneously influence employment, or labor saving or displacing technologies that may drive imports could also be correlated with domestic employment. We use an instrumental variable to address these endogeneity concerns. Specifically, we instrument Chinese imports to India (given by equation 1) by Chinese imports to a set of countries, following Autor et al. (2013) and Acemoglu et al. (2016), as given by:

$$
I V_{j t}^{\text {China }}=\frac{M_{j t}^{\text {Others }}}{\left(Y_{j, 94}+M_{j, 94}-X_{j, 94}\right)}
$$

where $M_{j t}^{\text {Others }}$ refers to Chinese imports to industry $j$ in time $t$ in a set of Latin American countries, namely Argentina, Brazil, Costa Rica, Chile, Colombia, Mexico, Paraguay, Peru, Uruguay, and Venezuela. ${ }^{19}$ The instrument isolates the variation in Chinese imports that is only due to supply side shocks from China. Chinese imports to the instrument-country list are expected to be strongly correlated with Chinese imports to India if the basket of

\footnotetext{
${ }^{19}$ While tariffs have been used as instrumental variables for imports in many contexts, in India, tariffs are not exogenous post 1996 (Topalova and Khandelwal, 2011).
} 
goods exported from China to India and these countries are similar, and if these countries experienced similar rise in Chinese exports. This assumption is testable.

Figure 1 shows the evolution of Chinese import share from 1998 to 2007 for India and various country groups. The rise in the Chinese import share was very similar for India and the instrument-countries. Further, the choice of Latin American countries ensures that the exclusion criterion is likely to be satisfied, as these countries are not major trade partners with India, and thus the correlation between Chinese imports to these countries and India is solely due to the supply side component of Chinese imports arising from gains in manufacturing productivity for Chinese firms. All our empirical specifications also control for fixed effects at the state-year, industry(3-digit)-year, and state-(4-digit)industry- levels to control for unobservables.

We further take into account alternative trade channels (varying at the same level as our import competition measure) that could influence employment, and that are potentially correlated with Chinese imports. We control for Chinese imports in inputs to an industry to account for the confounding effect from access to potentially cheaper Chinese inputs. Further, concurrent changes in trade policy may be correlated with Chinese imports to India, which is addressed by controlling for industry level output and input tariffs. Another concern is that Chinese imports to India may be correlated with imports from other countries. To address this, we control for import penetration in India from low- and middle-, and high-income countries in all specifications. Further, Chinese imports to India may also be correlated with Chinese imports into other countries, and our estimates may capture the effect of increased competition from China in destination markets for Indian exporters. To address this, we control for Chinese import share in low- and middle-, and high-income countries, excluding the set of IV countries. Finally, we control for India's exports to the IV countries to control for the direct effect of Chinese import competition for Indian exporters in these countries. ${ }^{20}$

\footnotetext{
${ }^{20}$ We discuss the construction of these variables in Appendix A.
} 


\subsection{Decomposition of Overall Change in Formal Share in Em- ployment}

Since we examine within industry changes in the share of formal enterprise employment as a response to Chinese import competition, it is important to confirm that across-industry changes in employment is not a major contributor to overall changes in industry employment. We start by analyzing whether the changes in formal share in our study period is driven by industries with high/low formal share increasing their employment share in manufacturing (between), or due to changes in formal share with the industry (within). For this, we decompose the overall change in formal enterprise share in employment, $\Delta F W$, between 2000-2001 and 2005-2006 into the respective within and between industry components as follows:

$$
\Delta F W=\sum_{j}\left(0.5 *\left(s_{j t}+s_{j t-1}\right)\right) \Delta f w_{j t}+\sum_{j}\left(0.5 *\left(f w_{j t}+f w_{j t-1}\right)\right) \Delta s_{j t}
$$

where $f w_{j t}$ denotes formal share in employment for industry $j$ in year $t$, and $s_{j t}$ denotes employment share of industry $j$ in total employment in manufacturing. We aggregate employment at the industry level, using the ASI-NSS data, to conduct this analysis. The first term captures the change in formal share in employment due to changes in formal sector employment across firms within an industry whereas the second term captures movement of formal workers across industries. Table 2 reports the decomposition between 2000-2001 and 2005-2006 using the firm level surveys. We find that change in overall formal share in employment is predominantly driven by within-industry change (column 2) and that the magnitude of the between-industry effect is relatively small (column 3). We obtain similar results if we decompose the share of contract workers and the share of regular workers. The relationship between import competition and formal share in employment we explore in this paper also similarly highlights within-industry changes in response to increased import competition from China. Next, we turn to a more rigorous examination of the link between Chinese import competition and formalization in our empirical analysis. 


\section{Results}

To examine the relationship between Chinese import competition and formal share of employment, we use both enterprise surveys (ASI-NSS) in Section 5.1 and worker surveys (EUS) in Section 5.2. We test for heterogeneity based on labor institutions in Section 5.3. Having established the positive effect of Chinese imports on formal share of employment, we focus on the formal sector, and examine within-firm employment changes and heterogeneity in responses based on initial productivity (Section 5.4).

\subsection{Aggregate Changes in Formal Employment}

We employ the ASI-NSS data to study the relationship between Chinese import competition and the aggregate formal share of employment at the state-industry level. We estimate the following specification:

$$
Y_{j s t}=\beta_{1} I M P_{j t-1}^{c h i n a}+\mathbf{Z}_{j t-1} \psi+\alpha_{j(3) t}+\alpha_{s t}+\alpha_{j s}+\nu_{j s t}
$$

where $Y$ is either the share of formal sector employment in total employment or (log of) total, informal, formal, formal-regular and formal-contract employment. $s$ denotes a state, and $j$ denotes an industry defined at the 4-digit level (NIC 2004). Our main explanatory variable is the industry level (at 4-digit) import penetration ratio for Chinese imports, $I M P_{j t-1}^{\text {China }} \cdot{ }^{21} \mathbf{Z}_{j t-1}$ is a vector of variables capturing alternative trade channels (described in Section 4). We control for state $\times$ industry $\left(\alpha_{j s}\right)$, state $\times$ year $\left(\alpha_{s t}\right)$, and three-digit industry $\times$ year $\left(\alpha_{j(3) t}\right)$ fixed effects to control for unobservables. We cluster robust standard errors at the industry level which is the level of variation of our treatment variable. Regressions are weighted by the state-industry employment in the initial year, $2000-2001 .^{22}$

\footnotetext{
${ }^{21}$ We use a lagged measure of Chinese import penetration to alleviate endogeneity concerns related to anticipatory employment responses to Chinese import competition, and to ensure that we study employment responses to past changes in import competition.

${ }^{22}$ Weights could be: (1) initial total employment if the outcome is share of formal employment or total employment; (2) initial informal employment if the outcome is informal employment, and (3) initial formal employment if the outcome is either total formal, regular, or contract employment.
} 
Table 3 reports the results. Panel $\mathbf{A}$ and $\mathbf{B}$ report results from OLS and IV estimation of the specification, respectively. The first stage F statistics suggest a strong first stage relationship between our IV and the endogenous variable. In column (1), the coefficient on $I M P_{j t-1}^{c h i n a}$ is positive and significant, suggesting that a one percentage point increase in Chinese import competition leads to an increase in formal share of employment by 1.55 percentage points at the state-industry level. The coefficient is statistically significant in the IV regression. ${ }^{23}$

In columns (2)-(4), we document the effect of Chinese import competition on the (log of) overall employment, informal, and formal sector employment, respectively. The results indicate that a one percentage point increase in Chinese import competition leads to a decline in overall employment by $7.96 \%$, decline in informal employment by $15.75 \%$, and an increase in formal sector employment by $4.39 \%$. Thus, Chinese import competition induces a large decline in informal sector employment while increasing formal sector employment, leading to an increase in formal share in employment. Taken together, these results suggest that Chinese import competition led to a reallocation of employment from the informal to the formal sector. We further disaggregate formal sector employment into regular (column 5) and contract workers (column 6) to identify the source of increase in formal sector employment observed in column (4). The rise in formal employment is largely driven by contract labor. A one percentage point increase in Chinese import competition leads to an increase in regular employment by $3.53 \%$ and contract employment by $10.59 \%{ }^{24}$

As discussed earlier in Section 2, Chinese import competition may also lead to increase in the informality in the exposed industries as formal firms and workers transition to the informal sector (Dix-Carneiro et al., 2021; Dix-Carneiro and Kovak, 2019). Further, formal firms may subcontract manufacturing activities to the informal sector to save cost Chakraborty and Sundaram (2020). Our findings suggests that while these mechanisms may be present, they are dominated by the reallocation of activity from the informal to the formal sector as unproductive informal firms exit in response to greater competition.

\footnotetext{
${ }^{23}$ Our results are robust to clustering at the broader NIC 3-digit industry as well as controlling for an industry's exposure to de-reservation of SSI. Results are reported in Table B1 (Appendix B).

${ }^{24} \mathrm{We}$ obtain qualitatively similar results if we estimate variants of Equation 4 at the industry level, rather than at the state-industry level. We report these results in Table B2 (Appendix B).
} 
Table B3 reports results from estimating variants of Equation (4) for number of factories and sales as outcome variables. We find that there was net exit from the informal sector (column 1) and net entry into the formal sector (column 2). Similarly, columns (3) and (4) suggest that informal sector sales declined and there was no effect on sales of formal sector. $^{25}$

\subsection{Worker Transitions to Formal Sector}

Next, using the EUS data, we estimate the effect of Chinese import competition on the probability of a worker being employed in the formal sector:

$$
\text { formal }_{i j s t}=\beta_{1} I M P_{j t-1}^{C h i n a}+\mathbf{X}_{i j s t} \delta+\mathbf{Z}_{j t-1} \psi+\alpha_{j(3) t}+\alpha_{s t}+\alpha_{j s}+\nu_{i j s t}
$$

where $i$ denotes a worker and formal $_{i j s t}$, our outcome variable of interest, is an indicator variable which is equal to 1 if a worker is employed in the formal sector. $\mathbf{X}_{i j s t}$ is a vector of worker characteristics that includes age, indicators for gender, education, marital status, religious minority, disadvantaged social groups, and residence in rural areas. ${ }^{26}$. We cluster robust standard errors at the industry level. Regressions are weighted using sample weights from the survey.

Table 4 reports the results from Equation (5) and its variants from OLS (columns 1-3) and IV (columns 4-6) estimations. We present the specification excluding (columns 1 and 4) and including controls for worker characteristics (columns 2 and 5), and their interaction with an indicator variable for the year 2004-2005 to control for changes in

\footnotetext{
${ }^{25}$ Import competition could also lead to increase in employment in the non-manufacturing sectors of the economy if the unemployed manufacturing workers get absorbed by these sectors. Following Autor et al. (2013), we calculate the exposure of each district to Chinese import competition. We use EUS survey to calculate district level employment in manufacturing, agriculture and mining, and services. Table B4 reports the result from estimating a district level regression of Chinese import competition on employment outcomes. The effect of Chinese import competition on overall employment is negative but imprecisely estimated. Further, districts more exposed to Chinese import competition experience a large decline in manufacturing employment consistent with our results in Table 3. We find no significant effect on employment in the agriculture and mining, and services sectors.

${ }^{26}$ Educational categories include primary and below, below secondary, and secondary and higher education. Social group categories in India include the Scheduled Caste, Scheduled Tribes, Other Backward Castes, and Other Castes.
} 
worker characteristics between the two sample rounds (columns 3 and 6$).{ }^{27}$ The first-stage F-statistics for the IV estimates in columns (4)-(6) imply a strong relationship between our instrument and $I M P_{j t-1}^{C h i n a}$. The coefficient on $I M P_{j t-1}^{C h i n a}$ is positive and significant in all columns suggesting that increase in Chinese import competition significantly increases the probability of being employed in a formal enterprise. The coefficient in our preferred specification in column (6) implies that a one percentage point change in Chinese import competition leads to an increase in the probability of being employed in a formal enterprise by 0.47 percentage points. For an industry that experiences a change in $I M P$ equivalent to the average change between the two survey rounds, 0.05 , our coefficient translates to an overall increase in formal sector employment by 2.35 percentage points.

Next, we report robustness checks for the main results in Table B5 (Appendix B). In column (1), we find that our results are robust to clustering the standard errors at a more aggregated industry level (NIC 3-digit). Martin et al. (2017) find higher employment growth in the formal sector is in response to de-reservation of SSI products. If de-reservation of SSI products is systematically related to Chinese imports, this could lead to spurious correlation between increase in Chinese imports and formal employment. Column (2) controls for de-reservation exposure of each industry and the coefficient remains statistically significant with very similar magnitudes compared to the baseline results. ${ }^{28}$ Finally, we show robustness to an alternative definition of informality. Recall that we reclassified workers as formal if they report working for a firm that is registered even if they are deemed to be working in an informal firm based on the size threshold. In column (3), we reclassify these workers as informal, and find that our results continue to be robust. In column (4), we drop these reclassified workers from the estimation sample and our results continue to remain robust. Thus, the increase in the aggregate level results from enterprise surveys is corroborated by the increase in the probability of formal sector employment observed in the worker level surveys. It is encouraging that our results are qualitatively consistent across two independent data sources.

\footnotetext{
${ }^{27}$ We find positive and significant effects when we estimate specification in column (3) using a Probit model (results available on request).

${ }^{28}$ We use data on product level de-reservation from Martin et al. (2017) and construct an indicator variable equal to 1 if at least one product is dereserved in that industry.
} 
The overall effects documented above could mask considerable heterogeneity based on worker characteristics, because workers may have different adjustment costs based on demographic characteristics (Dix-Carneiro, 2014), and because firms may have differential demand for workers based on these characteristics in response to Chinese import competition. Next, we test for worker heterogeneity based on age, education, and location.

Table B6 (Appendix B) shows that the overall results are primarily driven by experienced workers between 30 and 45 years of age (column 2) while the effect is weaker and statistically significant at the $10 \%$ level for workers below 30 years of age (column 1) and is insignificant for older workers (column 3). These findings are consistent with a larger mobility costs for older compared to younger workers. Also, informal sector specific skills may not be perfectly transferable to the formal sector. On the other hand, we do not find any significant differences in transition to the formal sector based on education levels. The magnitude of the coefficients are larger for workers with education lower than secondary level (columns 1 and 2) compared to workers who have completed secondary education or higher (column 3). ${ }^{29}$ Lastly, we find that the overall effects are driven by workers in urban areas (column 8) with no significant effect on rural workers (column 7$).{ }^{30}$

\subsection{Heterogeneity Based on Institutions}

We expect the effect of Chinese import competition on transition of informal workers to the formal sector to be higher in settings where misallocation of workers across the two sectors is high to begin with. Labor market imperfections, such as EPLs, are often cited as a potential reason for the presence of informality (Besley and Burgess, 2004). However, the reallocation of workers to the formal sectors will be hindered in precisely these same settings as high firing costs would deter formal firms to absorb new workers (Hopenhayn

\footnotetext{
${ }^{29}$ These differences are not statistically significant. The higher magnitudes for workers with lower levels of education is suggestive of increase in demand for low skilled workers by formal firms in response to Chinese import competition. This finding is also consistent with the observed increase in contract workers, who are relatively low skilled compared to the regular workers, in the formal sector. We discuss these results in Section 5.1.

${ }^{30} \mathrm{~A}$ potential explanation of the null effects for rural workers may be that firms in rural areas are shielded from import competition due to relatively higher trade costs of reaching rural markets for imported Chinese goods.
} 
and Rogerson (1993); Kambourov (2009); Boedo and Mukoyama (2012)). Thus, in settings with high firing costs for formal firms, presence of alternative institutions, like contract labor, are needed to facilitate reallocation of workers to the formal sector.

In India, two sets of labor institutions, the Industrial Disputes Act, 1947 (IDA) and high unionization, lead to higher labor adjustment costs for large formal firms. ${ }^{31}$ During our study period, however, the institution of contract workers was already well established in India and had considerably relaxed these constraints for the large formal firms. Firms can hire contract workers under the Contract Labor Act 1970, and these workers are not under the ambit of the IDA, and are typically not a part of firm level unions. Indeed, in a period when contract workers were not prevalent, Adhvaryu et al. (2013) find that firms in states with pro-labor institutions do not adjust employment in response to rainfall shocks. On the other hand, Chaurey (2015) finds an increase in employment for formal firms driven by contract employment in response to rainfall shocks between 1998-2007.

We test for heterogeneous impacts based on labor institutions in India. First, we consider the IDA, that stipulates labor firing restrictions for large firms, but not for small firms. ${ }^{32}$ Several states have amended the IDA, leading to variation in the level of stringency with which it is applicable. We use a simple bifurcation of states into pro-worker and pro-employer categories based on the codification of the amendments to the IDA by Besley and Burgess (2004). ${ }^{33}$ Second, a strong union presence could potentially limit the size of the formal sector. We use the index by Dougherty (2009) of state level unionization rates, and classify states into high and low union states based on the median value of the index.

\footnotetext{
${ }^{31}$ Indeed, the pro-worker states and high unionization states have a higher share of informality compared to other states.

${ }^{32}$ Two aspects of the Industrial Disputes Act , 1947, are relevant. Under section V-A, in establishments with 50 or more workers, a worker who is retrenched could claim compensation for wages for 15 days for each year of service. If worker is laid-off, they must be provided half of their basic wage and a dearness allowance for each day they are laid off, for a maximum of 45 days. Establishments with 100 or more workers are covered under Section V-B, and requires firms to obtain government permission to lay-off or retrench even a single worker. Prior notification with the government is required if an establishment plans to close down (sixty days for Section V-A or ninety days for Section V-B).

${ }^{33}$ Besley and Burgess (2004) exploited state level amendments to the IDA to generate state level scores indicating the stringency of these laws. The larger the value, the higher the firing costs and more "proworker" the state is. On the other extreme, negative values indicate low firing costs and a "pro-employer" regime. Zero indicates neutrality. States with a positive score are classified as "pro-worker" states.
} 
We estimate Equations (5) and (4) separately for pro-worker and pro-employer states, and low and high unionization states. Results presented in Table $\mathbf{5}$ suggest that Chinese import competition differentially increases the probability of a worker being employed in a formal enterprise in high unionization (column 1) and pro-worker states (column 3), compared to low unionization (column 2) and pro-employer states (column 4). The results from firm surveys at the state-industry level in columns (5)-(8) corroborate the findings from the worker surveys in columns (1)-(4). Finally, as hypothesized, columns (9)-(12) provide strong evidence that the increase in the share of contract employment in total employment is also driven by firms in high unionization (column 9) and pro-worker (column 11) states.

\subsection{Within-Firm Employment in the Formal Sector}

To further examine the mechanism behind increase in formal sector employment, we exploit the availability of the establishment level panel dataset from the ASI between 1998-1999 and 2007-2008. This enables us to document the within firm changes in overall employment as well as composition of employment, contract and regular, for formal firms. We estimate the following specification:

$$
Y_{i j s t}=\beta_{1} I M P_{j, t-1}^{c h i n a}+\mathbf{Z}_{j t-1} \psi+\alpha_{i}+\alpha_{j(3) t}+\alpha_{s t}+\nu_{i j s t}
$$

where $i$ denotes a firm. $Y_{i j s t}$, the outcome variable, could denotes either (log of) total workers, regular workers, contract workers, or the contract worker ratio. In addition to the trade channels and fixed effects in Equation (4), we include firm fixed effects, $\alpha_{i}$, to control for time invariant firm level characteristics. Regressions are weighted using sample weights from the ASI.

Columns (1)-(4) and (5)-(8) of Table 6 report results from OLS and IV estimations, respectively. From our preferred IV specification in column (5), the coefficient on IMP is positive and significant suggesting that Chinese import competition also leads to an increase in firm level employment on average among formal sector firms. The effect on regular workers is negative, but statistically insignificant in the IV specification in column 
(6). The positive and significant coefficient in column (7) (contract workers) and column (8) (contract worker ratio) provides strong evidence that the overall increase in within firm employment in the formal sector is driven primarily by the increase in contract employment. The IV coefficients imply that for a one percentage point increase in Chinese import competition, there was an increase in within-firm employment in the formal sector by $0.11 \%$, contract workers by $0.31 \%$, and contract share in employment by 0.048 percentage points. Thus, our within firm level results mirror our earlier results, in Section 5.1, documenting an increase in aggregate employment, primarily through contract employment.

To identify the formal sector firms that expand employment in response to Chinese import competition, we estimate heterogeneous impacts based on initial productivity using the following regression specification:

$$
\begin{aligned}
Y_{i j s t}=\beta_{1} I M P_{j t-1}^{c h i n a}+\sum_{k=2}^{4} \beta_{k}\left(I M P_{j t-1}^{c h i n a} \times Q r_{k}\right)+\mathbf{Z}_{j t-1} \psi & \\
& +\alpha_{i}+\alpha_{j(3) t}+\alpha_{s t}+\alpha_{s j}+\nu_{i j s t}
\end{aligned}
$$

This specification is the same as Equation (6), but with additional interaction terms between $I M P_{j t-1}^{c h i n a}$ and indicator variables for the quartile the firm belongs to in the initial productivity distribution $\left(Q r_{k}\right)$. Productivity is computed using total factor productivity (TFP), and is captured in the first year in which firm appears in the data. We estimate the TFP using the methodology proposed by Ackerberg et al. (2015). Regressions are weighted using sample weights from the ASI.

Results are presented in Table 7. Column (1) indicates that there is a decline in employment in the lowest quartile although it is imprecisely estimated, and a differential increase in employment among firms in higher quartiles compared to firms in the lowest quartile. We observe similar results for regular (column 2), contract (column 3), and contract worker ratio (column 4). Thus, the overall increase in formal employment, driven by contract labor, documented in Table $\mathbf{3}$ is led by the high productivity formal firms. 


\section{Reallocation and Aggregate Labor Productivity}

To quantify the aggregate labor productivity gains from Chinese import competition, we use information on the share of workers that are reallocated from informal to formal sector $\left(S_{f}\right)$ and the increase in labor productivity for a worker moving from informal to formal sector $\left(\Delta \omega_{f}\right)$. The labor productivity gain from reallocation can then be computed as $\Delta \omega=$ $S_{f} \Delta \omega_{f}$. The calculation of $S_{f}$ is straightforward and we compute it using the coefficient $(\beta)$ on $I M P_{j t-1}^{c h i n a}$ in Table 3. Specifically, $S_{f}=\sum_{s j} m_{s j}(\beta \times \Delta I M P)$, where $m_{s j}$ is each stateindustry's share in overall manufacturing employment and $\triangle I M P$ is the industry level change in Chinese import competition between 2000-2001 and 2005-2006. The estimates imply an overall change in formal share of employment by 4.1 percentage points. Obtaining accurate estimates of labor productivity gap between formal and informal sector, however, is more challenging due to measurement issues and unobserved heterogeneity in characteristics of the two sectors. Below, we describe the procedure to calculate the labor productivity gap between the two sectors and discuss potential issues associated with these calculations and how we address them.

\subsection{Development Accounting Framework}

We consider an industry comprised of two types of firms, formal and informal, that differ in their total factor productivity (TFP). Assuming a Cobb-Douglas production function with labor and capital as factor inputs, competitive markets, and homogeneous labor, it can be shown that the ratio of marginal product of labor between the two sectors equals the wage ratio as well as the ratio of the average product of labor. ${ }^{34}$ Formally, let the production function for each sector be given by $Y_{s}=A_{s} K_{s}^{\alpha_{s}} L_{s}^{1-\alpha_{s}}$, where $Y_{s}$ is real output, $K_{s}$ and $L_{s}$ are capital and labor inputs, respectively, $A_{s}$ denotes the TFP, and $\alpha_{s}$ is the output elasticity with respect to capital. Under the assumption of perfect competition and homogeneous labor in the two sectors, the wages $(w)$ equal the marginal revenue product of labor (MRPL) which in turn is equal to the product of output elasticity with respect to

\footnotetext{
${ }^{34}$ These assumptions are standard in the development accounting framework (Caselli, 2005)
} 
labor and the average revenue product of labor (ARPL).

$$
w_{s}=M R P L_{s}=\left(1-\alpha_{s}\right) A R P L_{s}
$$

Assuming that the output elasticity of labor, $1-\alpha$, is same across the two sectors, we can represent the MRPL gap between the two sectors in terms of obervables.

$$
\frac{w_{f}}{w_{i}}=\frac{M R P L_{f}}{M R P L_{i}}=\frac{A R P L_{f}}{A R P L_{i}}
$$

where $f$ and $i$ denote the formal and informal sector, respectively.

Thus, the labor productivity gap between formal and informal sector can be calculated using revenue per worker or wages. ${ }^{35}$ However, using the above framework entails strong assumptions and there are several issues with the above approach. First, the ARPL gap as measured by revenue per unit labor would also capture price differences arising from markup and demand shocks across the two sectors. To address this, one needs to observe firm level prices which is rarely observed in the data, especially for the informal sector. Second, worker characteristics may be significantly different for workers across the two sectors which would contaminate the measure of productivity gap. Thirdly, the estimates may suffer from measurement issues in output as well as inputs. Fourth, the output elasticity with respect to labor may be significantly different across the two sectors. In the following section, we document the unadjusted labor productivity gap using Equation (8) and sequentially adjust the productivity gap to address each of the issues discussed above.

\subsection{Labor Productivity Gap}

We observe wages, number of workers, and revenue in our firm level datasets for both the informal and formal sectors, and hence are able to calculate the productivity gap using both wages and revenue per worker using Equation (8). ${ }^{36}$ Table 8 reports the productivity

\footnotetext{
${ }^{35}$ McCaig and Pavcnik (2018) use both wages and revenue per worker to measure productivity gap between the household and enterprise sector in Vietnam. Gollin et al. (2014) use revenue per worker, while Vollrath (2014) use the wage gap to measure productivity differences between the agricultural and non-agricultural sectors.

${ }^{36}$ Wages are calculated as total wages per worker paid by firms in a given year.
} 
gap results based on revenue per worker in column (1) and wages in column (2). In the first row, we report the unadjusted raw gap in labor productivity between the formal and informal sector. The gap is well above one in both columns, suggesting potentially large productivity gains from reallocation of workers to the formal sector. The average revenue per worker is almost 11 times higher in formal sector compared to the informal sector, while this ratio is only 3.12 with wages. This larger gap in average revenue product of labor compared to wages is consistent with the literature (McCaig and Pavcnik, 2018; Nataraj, 2011). However, as discussed earlier in Section 6.1, this raw productivity gap may be contaminated with measurement error and heterogeneity across the two sectors in the output and input characteristics. Next, we discuss the main factors that may be driving the large observed productivity gap and how we address these concerns in our calculations.

Differences in Hours Worked: We adjust the productivity gap for differences in the average number of hours worked across the two sector. The number of hours worked may not be proportional to the number of workers due to two reasons. First, a lot of informal firms do not operate for the whole year and this would lead to under estimation of actual productivity in the informal sector. Second, informal workers, on average, have lower working hours compared to their formal counterpart. We use information on the number of months in operation and average hours worked per day for informal firms, and number of working days and employment reported by the formal firms to adjust the raw productivity gap. ${ }^{37}$ A detailed description of the adjustment calculations is provided in the Appendix Section $\mathbf{C}-\mathbf{C 0 . 2}$. This adjustment lowers the productivity gap to 5.09 and wage gap to 1.45 and is reported in row (2).

Human Capital Differences: Another concern with our measured productivity gap is that we may be capturing differences in human capital between the two sectors. Following Gollin et al. (2014), we adjust for human capital differences in the two sectors using data on the level of education reported in the NSSO employment-unemployment surveys. The adjustment procedure is described in Appendix Section $\mathbf{C}-\mathbf{C 0 . 3}$. This adjustment

\footnotetext{
${ }^{37}$ This information is available only in the 2005 round of the ASI-NSS surveys. By utilizing this data to correct for differences in hours worked across the two sectors in the 2000 ASI-NSS round, we assume that average number of hours worked across the two sectors do not change significantly between the two survey rounds.
} 
reduces the revenue productivity gap in column (1) to 4.21, and wage gap in column (2) to 1.21. Thus, differences in hours worked and human capital across the two sectors explain a significant part of the unadjusted labor productivity gap (72.2\%) and wage gap (96.7\%).

A remaining concern is that the large observed labor productivity gap and wage gap between the sectors (Table 8) is due to other unobserved worker characteristics, besides the years of education and number of hours worked. If this is the case, the productivity and wage gap may be overestimated. To account for heterogeneity in worker characteristics other than hours worked and human capital, we use the EUS survey (worker level) and estimate Mincerian regressions of log wages on an indicator variable for formal sector employment, and worker characteristics such as years of education, location, and sociodemographic characteristics. We also include industry and state fixed effects to control for industry and state specific unobservables that are correlated with both formal employment and wages. The coefficient on the indicator variable gives us the wage premium associated with working in the formal sector.

Table B7 reports the results. In column (1), without controlling for worker characteristics, we find that there is a $31.4 \%$ wage premium for formal sector workers as compared to a wage premium of $22.1 \%$ in column (3) which controls for education level of workers. The wage premium further drops to $17.4 \%$ for formal sector workers compared to those in the informal sector in the specification including all worker characteristics (column 7). This suggest that there is a significant wage premium for formal sector workers even after controlling for levels of education and other worker characteristics.

Differences in Prices: A well documented issue with measuring productivity from revenue data is that the productivity measure will capture the effect of prices, due to markup differences and demand shocks, in addition to the actual labor productivity (McCaig and Pavcnik, 2018). ${ }^{38}$ Accounting for differences in prices is typically not feasible due to unavailability of data on physical production in addition to revenue. This information is rarely available even for formal sector firms. The firm level surveys in India are unique in that they capture detailed production data for both formal and informal firms. We directly

\footnotetext{
${ }^{38}$ See De Loecker and Warzynski (2012) and De Loecker et al. (2016) for a discussion of issues with estimation of productivity from revenue data.
} 
observe the quantity manufactured, units of production, and revenues for each product produced by the firm. ${ }^{39}$ This enables us to adjust for the differences in prices across the informal and formal sector. We are not aware of any other dataset that documents physical production for a representative sample of informal firms.

We adjust for price differences by computing firm level prices. First, we calculate the firm-product level prices (unit values) as sales divided by physical quantity for each firmproduct. We compute the firm level price index as sales-share weighted sum of firm product level prices. Next, we calculate the firm level real output by deflating nominal revenue by firm level prices. We compare the revenue productivity gap from nominal revenue to that from real revenue per worker gap and estimate the adjustment factor to be 1.73. We provide detailed explanation of the procedure employed to correct for price differences in

\section{Appendix Section C - C0.4..$^{40}$}

We adjust the productivity gap for differences in prices using the correction factor of 1.73 and the productivity gap drops to 2.18 in column (1) of Table 8 . Thus, differences in prices explain a significant part of the observed revenue productivity gap across the formal and informal sector and failure to correct for price differences would lead to significant overestimation of potential labor productivity gains from reallocation. The estimates suggest that differences in prices account for $57 \%$ of the revenue productivity gap.

Measurement Error in Output: Another issue with the estimated productivity gap is that it may be driven by measurement errors in output. We account for the under-reporting of revenues in the informal sector, and following De Mel et al. (2009), assume that revenues were $30 \%$ higher than reported in the informal sector, and adjust our productivity gap in

\footnotetext{
${ }^{39}$ This information is available only in the 2005 round of the ASI-NSS surveys. By utilizing this data for correcting price differences across the two sectors in the 2000 ASI-NSS round requires the assumption that average price differences across the two sectors do not change significantly between the two survey rounds.

${ }^{40}$ Alternatively, we also utilize the availability of information on physical quantities at the firm product level and calculate the physical quantity per worker for both sectors. We allocate workers to each firmproduct in proportion to the revenue share of the firm product in total firm revenues. Then we take the ratio of revenue per worker gap to quantity per worker gap in each product category to arrive at the adjustment factor. Note that we need quantity to be reported in the same units to be able to perform this calculation. Thus, this calculation is based on a subset of 1600 product lines for which both formal and informal sector datasets report quantities in the same units. We take a sales share weighted sum of the product level adjustment factor and arrive at the overall adjustment factor for differences in prices. The calculations suggest an adjustment factor of 1.67. Thus, we find similar effects of prices in explaining the revenue productivity gap using both methods.
} 
column (1) to 1.53 .

Differences in Output Elasticity of Labor: A remaining concern is that there may be differences in the output elasticity between the formal and the informal sectors. Following Fernandes and Paunov (2009), we assume that the output elasticity of labor in the formal and informal sectors are 0.65 and 0.8 , respectively. We adjust the productivity gap by a factor of 1.23 and this adjustments reduces the gap in column (1) to 1.24.

\subsection{Productivity Gains from Chinese Import Competition}

We estimate the aggregate productivity gains, relative to the baseline average labor productivity in the manufacturing sector, from reallocation in response to Chinese import competition using the formula below:

$$
\Delta \omega=\frac{S_{f}\left(A R P L_{\text {gap }}-1\right) A R P L_{i}}{\left(1-s_{i}\right) A R P L_{f}+s_{i} A R P L_{i}}
$$

where $A R P L_{\text {gap }}$ denotes the productivity gap between the two sectors, $A R P L$ denotes the average labor productivity in either the informal or formal sector,, and $s_{i}$ is the share of hours for informal sector in total hours worked. All these variables are defined in the 2000 ASI-NSS survey round.

We report productivity gains from three estimates of labor productivity gap in Table 8. The productivity gap in row (2), which adjusts for hours worked and human capital differences, implies an aggregate productivity increase of $5.13 \%$ due to reallocation of workers to the formal sector in response to increased Chinese import competition. Using estimates in row (3) that additionally control for price differences implies an aggregate productivity gain of $3.19 \%$. It is clear from these calculations that failure to correct for price differences greatly overestimates the overall productivity gains due to reallocation. We treat this estimate of $3.19 \%$ as the upper bound for productivity gains from Chinese import competition. Finally, we use estimates from row (5) that additionally correct for measurement error and differences in output elasticity of labor across the two sectors which implies an aggregate productivity gain of $0.89 \%$ (lower bound). Using a similar formula as Equation (9) for 
wages, our estimates suggest a modest gain in wages of $0.3 \%$ for workers transitioning to the formal sector (based on row (2) of column (2) in Table 8).

\section{Conclusion}

Extant literature provides mixed evidence on the relationship between import competition and informality. In this paper, we show that higher Chinese import competition increases the employment share in the formal sector in India. The rise in formal sector employment is driven by contract worker employment in more productive formal firms. In contrast, informal sector employment shrinks in response to Chinese import competition. By inducing reallocation of workers from the informal to the formal sector, Chinese import competition leads to aggregate labor productivity gains in the industry.

While we document an increase in the aggregate share of formal employment in response to Chinese import competition, disentangling the strengths of the extensive and intensive margins is not feasible due to data constraints. Further, our findings also suggest that the observed productivity gap between the formal and informal sector is considerably inflated and much of the gap is accounted for by differences in human capital, hours worked, and prices across the two sectors. Identifying the role of extensive and intensive margin adjustments in response to import competition, and accurately capturing the productivity gap between the informal and formal sectors remains a fruitful area for future research. 


\section{References}

Acemoglu, D., Autor, D., Dorn, D., Hanson, G. H., and Price, B. (2016). Import competition and the great us employment sag of the 2000s. Journal of Labor Economics, 34(S1):S141-S198.

Ackerberg, D. A., Caves, K., and Frazer, G. (2015). Identification properties of recent production function estimators. Econometrica, 83(6):2411-2451.

Adhvaryu, A., Chari, A. V., and Sharma, S. (2013). Firing costs and flexibility: evidence from firms' employment responses to shocks in india. Review of Economics and Statistics, 95(3):725-740.

Aghion, P., Bloom, N., Blundell, R., Griffith, R., and Howitt, P. (2005). Competition and innovation: An inverted-u relationship. The Quarterly Journal of Economics, 120(2):701-728.

Ahsan, R. N. and Mitra, D. (2014). Trade liberalization and labor's slice of the pie: Evidence from indian firms. Journal of Development Economics, 108:1-16.

Alder, S., Shao, L., Zilibotti, F., et al. (2013). The effect of economic reform and industrial policy in a panel of chinese cities. Center for Institutions, Policy and Culture in the Development Process, Working Paper, 207.

Allcott, H., Collard-Wexler, A., and O'Connell, S. D. (2016). How do electricity shortages affect industry? evidence from india. American Economic Review, 106(3):587-624.

ASSOCHAM (2013a). Chinese toys trigger attrition in indian smes: The indian toy industry fighting for its survival. Business Standard, August 08, 2013. Accessed: November 30, 2020.

ASSOCHAM (2013b). uge imports from china impacting domestic ceramics industry. $A S$ SOCHAM Study, April 18, 2013. Accessed: November 30, 2020. 
Asturias, J., García-Santana, M., and Ramos, R. (2019). Competition and the welfare gains from transportation infrastructure: Evidence from the golden quadrilateral of india. Journal of the European Economic Association, 17(6):1881-1940.

Autor, D. H. (2003). Outsourcing at will: The contribution of unjust dismissal doctrine to the growth of employment outsourcing. Journal of labor economics, 21(1):1-42.

Autor, D. H., Dorn, D., and Hanson, G. H. (2013). The china syndrome: Local labor market effects of import competition in the united states. American Economic Review, 103(6):2121-68.

Autor, D. H., Dorn, D., and Hanson, G. H. (2016). The china shock: Learning from labormarket adjustment to large changes in trade. Annual Review of Economics, 8:205-240.

Autor, D. H., Dorn, D., Hanson, G. H., and Song, J. (2014). Trade adjustment: Workerlevel evidence. The Quarterly Journal of Economics, 129(4):1799-1860.

Bertrand, M., Hsieh, C.-T., and Tsivanidis, N. (2015). Contract labor and firm growth in india. Technical report, Mimeo.

Besley, T. and Burgess, R. (2004). Can labor regulation hinder economic performance? evidence from india. The Quarterly journal of economics, 119(1):91-134.

Besley, T. and Persson, T. (2013). Taxation and development. In Handbook of public economics, volume 5, pages 51-110. Elsevier.

Bloom, N., Draca, M., and Van Reenen, J. (2016). Trade induced technical change? the impact of chinese imports on innovation, it and productivity. The Review of Economic Studies, 83(1):87-117.

Boedo, H. and Mukoyama, T. (2012). Evaluating the effects of entry regulations and firing costs on international income differences. Journal of Economic Growth, 17(2):143$-170$. 
Branstetter, L. and Lardy, N. (2006). China's embrace of globalization. Technical report, National Bureau of Economic Research.

Caselli, F. (2005). Accounting for cross-country income differences. Handbook of economic growth, 1:679-741.

Chakraborty, P. and Raveh, O. (2018). Input-trade liberalization and the demand for managers: Evidence from india. Journal of International Economics, 111:159-176.

Chakraborty, P. and Sundaram, A. (2020). Import competition, labour market regulations, and outsourcing. Mimeo, Lancaster University.

Chaurey, R. (2015). Labor regulations and contract labor use: Evidence from indian firms. Journal of Development Economics, 114:224-232.

Chen, Y., Jin, G. Z., and Yue, Y. (2010). Peer migration in china. Technical report, National Bureau of Economic Research.

Cisneros-Acevedo, C. (2019). Unfolding trade effect in two margins of informality. the peruvian case. Technical report, working paper.

Costa, F., Garred, J., and Pessoa, J. P. (2016). Winners and losers from a commoditiesfor-manufactures trade boom. Journal of International Economics, 102:50-69.

De Loecker, J., Goldberg, P. K., Khandelwal, A. K., and Pavcnik, N. (2016). Prices, markups, and trade reform. Econometrica, 84(2):445-510.

De Loecker, J. and Warzynski, F. (2012). Markups and firm-level export status. American economic review, 102(6):2437-71.

De Mel, S., McKenzie, D., and Woodruff, C. (2009). Measuring microenterprise profits: Must we ask how the sausage is made? Journal of development Economics, 88(1):1931. 
De Mel, S., McKenzie, D., and Woodruff, C. (2013). The demand for, and consequences of, formalization among informal firms in sri lanka. American Economic Journal: Applied Economics, 5(2):122-50.

Dix-Carneiro, R. (2014). Trade liberalization and labor market dynamics. Econometrica, $82(3): 825-885$.

Dix-Carneiro, R., Goldberg, P. K., Meghir, C., and Ulyssea, G. (2021). Trade and informality in the presence of labor market frictions and regulations. Technical report, National Bureau of Economic Research.

Dix-Carneiro, R. and Kovak, B. K. (2019). Margins of labor market adjustment to trade. Journal of International Economics, 117:125-142.

Dougherty, S. M. (2009). Labour regulation and employment dynamics at the state level in india. Review of Market Integration, 1(3):295-337.

Fernandes, A. M. and Paunov, C. (2009). Does tougher import competition foster product quality upgrading?

Goldberg, P. K. and Pavcnik, N. (2003). The response of the informal sector to trade liberalization. Journal of Development Economics, 72(2):463 - 496.

Gollin, D., Lagakos, D., and Waugh, M. E. (2014). The agricultural productivity gap. The Quarterly Journal of Economics, 129(2):939-993.

Gutiérrez, G. and Philippon, T. (2017). Declining competition and investment in the us. Technical report, National Bureau of Economic Research.

Hopenhayn, H. and Rogerson, R. (1993). Job turnover and policy evaluation: A general equilibrium analysis. Journal of Political Economy, 101(5):915-938.

Hsieh, C.-T. and Klenow, P. J. (2009). Misallocation and manufacturing tfp in china and india. The Quarterly journal of economics, 124(4):1403-1448. 
Kambourov, G. (2009). Labour market regulations and the sectoral reallocation of workers: The case of trade reforms. The Review of Economic Studies, 76(4):1321-1358.

Khan, T. (2014). Dragon on the rampage. Business Line, March 2, 2014. Accessed: November 30, 2020.

Levy, S. (2010). Good intentions, bad outcomes: Social policy, informality, and economic growth in Mexico. Brookings Institution Press.

Lucas Jr, R. E. (1978). On the size distribution of business firms. The Bell Journal of Economics, pages 508-523.

Mansour, H., Medina, P., and Velasquez, A. (2020). Import competition and gender differences in labor reallocation.

Martin, L. A., Nataraj, S., and Harrison, A. E. (2017). In with the big, out with the small: Removing small-scale reservations in india. American Economic Review, 107(2):35486.

McCaig, B. and Pavcnik, N. (2018). Export markets and labor allocation in a low-income country. American Economic Review, 108(7):1899-1941.

McKenzie, D. (2017). Identifying and spurring high-growth entrepreneurship: Experimental evidence from a business plan competition. American Economic Review, 107(8):22782307.

Melitz, M. (2018). Trade competition and reallocations in a small open economy. In World Trade Evolution, pages 60-81. Routledge.

Melitz, M. J. (2003). The impact of trade on intra-industry reallocations and aggregate industry productivity. econometrica, 71(6):1695-1725.

Ministry of Statistics and Programme Implementation (2000). Input output transactions table 1993-94. http://www.mospi.gov.in/publication/ input-output-transactions-table-1993-94. Accessed: May 5, 2019. 
Nataraj, S. (2011). The impact of trade liberalization on productivity: Evidence from india's formal and informal manufacturing sectors. Journal of International Economics, 85(2):292-301.

Naughton, B. J. (2006). The Chinese economy: Transitions and growth. MIT press.

Paz, L. S. (2014). The impacts of trade liberalization on informal labor markets: A theoretical and empirical evaluation of the brazilian case. Journal of International Economics, $92(2): 330-348$.

Rocha, R., Ulyssea, G., and Rachter, L. (2018). Do lower taxes reduce informality? evidence from brazil. Journal of Development Economics, 134:28 - 49.

Roy, V. (2013). Ludhiana cycle parts makers hit by cheap chinese imports. Business Standard, November 4, 2013. Accessed: November 30, 2020.

Saha, B., Sen, K., and Maiti, D. (2013). Trade openness, labour institutions and flexibilisation: Theory and evidence from india. Labour Economics, 24:180-195.

Sathyanarayana (2014). Sivakasi crackers face threat from chinese intrusion. Deccan Herald, June 16, 2014. Accessed: November 30, 2020.

Topalova, P. and Khandelwal, A. (2011). Trade liberalization and firm productivity: The case of india. Review of economics and statistics, 93(3):995-1009.

Utar, H. and Ruiz, L. B. T. (2013). International competition and industrial evolution: Evidence from the impact of chinese competition on mexican maquiladoras. Journal of Development Economics, 105:267-287.

Vollrath, D. (2014). The efficiency of human capital allocations in developing countries. Journal of Development Economics, 108:106-118. 
Figure 1: Chinese Import Shares in India and Different Country Groups

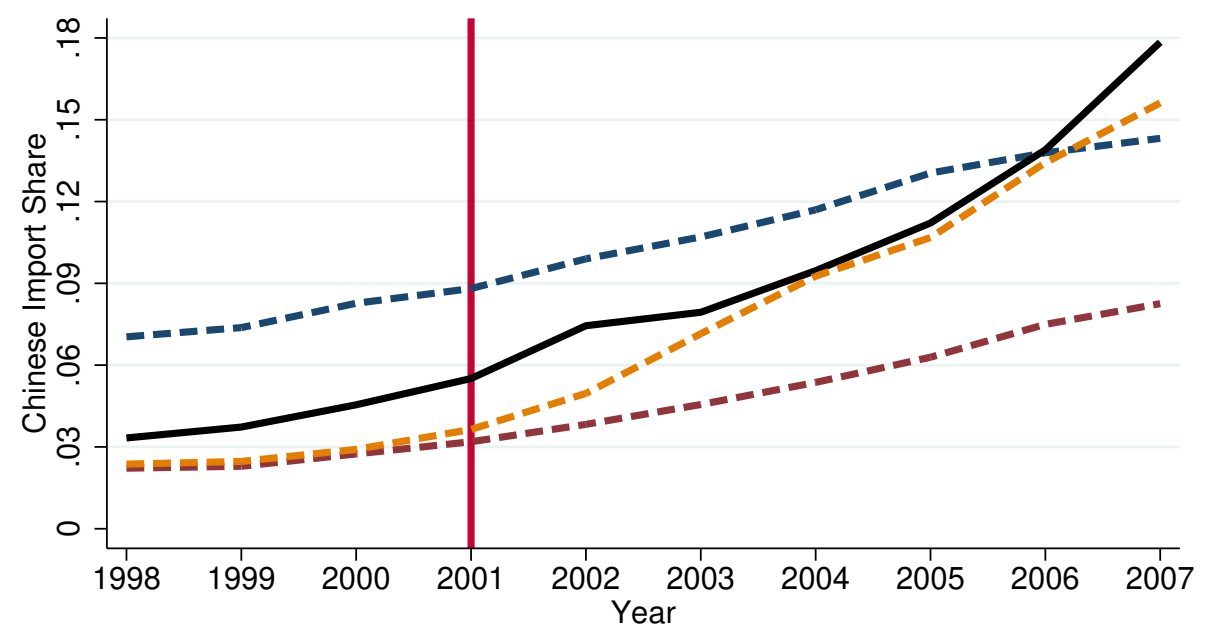

- - - - - Chinese import share in high income countries

- =-- Chinese import share in low and middle income countries

Chinese import share in India

- $=-$ Chinese import share in IV countries

Note: Chinese import share to a particular country is the share of imports from China in that country to all imports in that country. Data are sourced from the UN-COMTRADE database. 


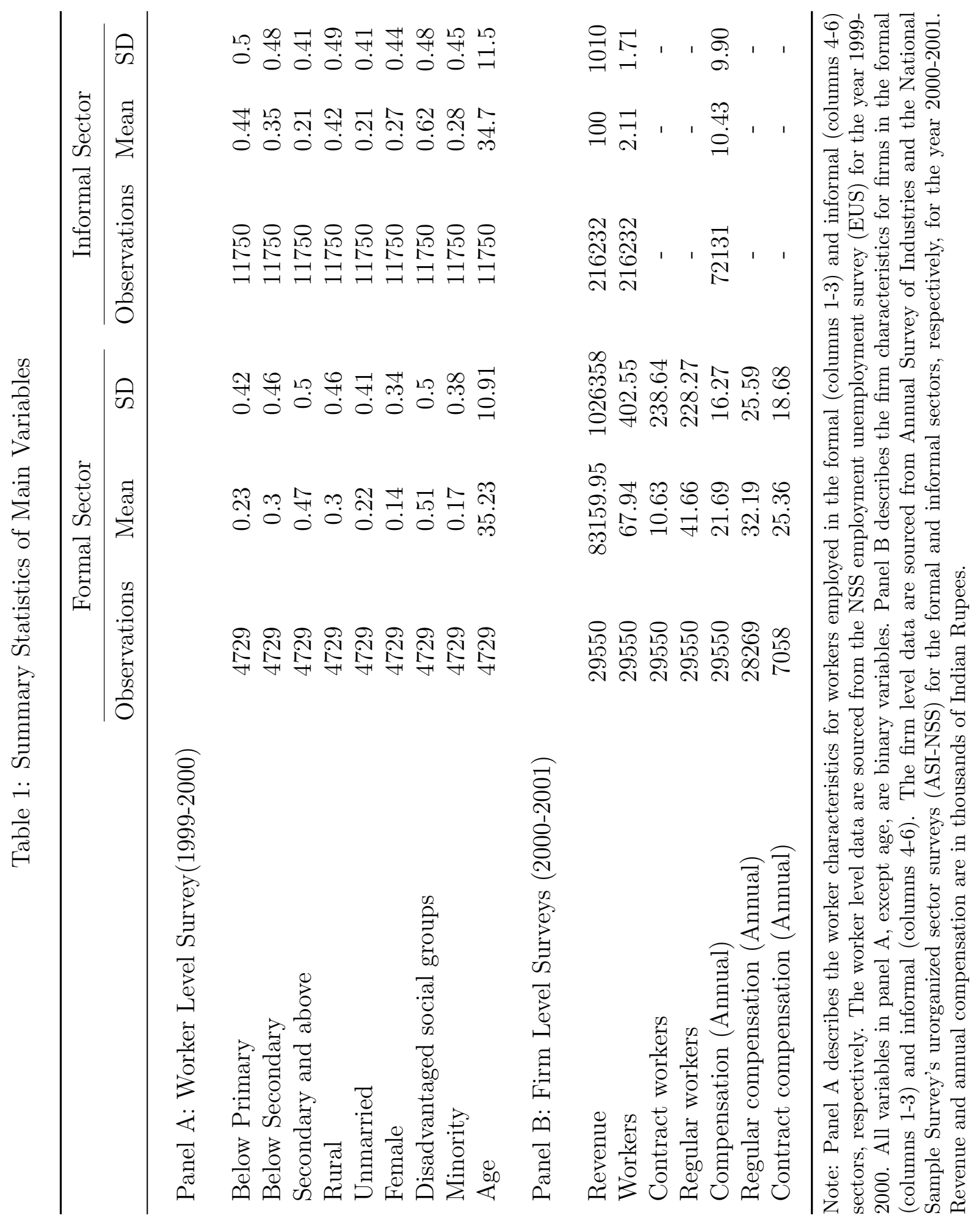


Table 2: Decomposition of Change in Employment Shares Between 2000-2001 and 2005-2006

\begin{tabular}{lccc}
\hline & $(1)$ & $(2)$ & $(3)$ \\
\hline & Total & Within & Between \\
\hline Formal Share in Employment & 0.0294 & 0.0248 & 0.0046 \\
Contract Share in Employment & 0.0197 & 0.0175 & 0.0022 \\
Regular Share in Employment & 0.0098 & 0.0073 & 0.0024
\end{tabular}

Notes: The table reports sectoral decomposition of changes in the share of employment of formal workers, contract workers, and regular workers in total employment between 2000-2001 and 2005-2006 using the Annual Survey of Industries, and NSSO's unorganized sector surveys. 
Table 3: Chinese Import Competition and Employment: State-Year Level Analysis

\begin{tabular}{|c|c|c|c|c|c|}
\hline \multirow{2}{*}{$\begin{array}{c}\text { Share in } \\
\text { total employment }\end{array}$} & \multicolumn{5}{|c|}{ Log Employment } \\
\hline & Total & Informal & & Formal & \\
\hline Formal & & & Total & Regular & Contract \\
\hline (1) & (2) & (3) & (4) & (5) & (6) \\
\hline
\end{tabular}

\begin{tabular}{lcccccc} 
Panel A: OLS & & & & & & \\
Chinese Import Competition (IMP) & 1.222 & $-6.972^{*}$ & $-14.17^{* *}$ & $4.605^{* *}$ & $3.335^{*}$ & $10.63^{* * *}$ \\
& $(0.778)$ & $(3.826)$ & $(6.437)$ & $(1.969)$ & $(1.799)$ & $(3.584)$ \\
Panel B: IV & & & & & & \\
Chinese Import Competition (IMP) & $1.546^{* *}$ & $-7.962^{*}$ & $-15.75^{* *}$ & $4.394^{*}$ & $3.534^{*}$ & $\begin{array}{c}10.59^{* * *} \\
(3.763)\end{array}$ \\
& $(0.710)$ & $(4.105)$ & $(6.285)$ & $(2.233)$ & $(2.090)$ & $(3.723 .01$ \\
\hline IV First-stage F-stat & 268.81 & 268.81 & 403.17 & 223.01 & 223.01 & 223.01 \\
Alternative Trade Channels & Yes & Yes & Yes & Yes & Yes & Yes \\
State $\times$ Industry FE & Yes & Yes & Yes & Yes & Yes & Yes \\
3-digit-industry $\times$ Year FE & Yes & Yes & Yes & Yes & Yes & Yes \\
State $\times$ Year FE & Yes & Yes & Yes & Yes & Yes & Yes \\
Observations & 3,702 & 3,702 & 3,182 & 2,912 & 2,912 & 2,912 \\
\hline
\end{tabular}

Note: Analysis is conducted at the 4-digit state-industry-year level. We use Annual Survey of Industries (ASI) to measure formal employment and the NSSO's unorganized sector surveys to measure informal employment. We use surveys conducted in 2000-2001 and 2005-2006. In the IV specifications, Chinese imports to India is instrumented with Chinese imports into a set of 10 Latin American countries. Alternative trade channels include output and input tariffs, access to Chinese inputs, import penetration from high income countries and low and middle income countries separately, Chinese import share in high income countries, Chinese import share in low and middle income countries, and India's export share in the total exports to the set of Latin American countries used to create the instrument. Regressions are weighted by total employment (column 1 and 2), informal employment (column 3), and formal employment (columns 4, 5, and 6) in the state-industry in the year 2000-2001. Robust standard errors clustered at the 4-digit industry level in parentheses. ${ }^{* * *}, * *, *$ is statistical significance at $1 \%, 5 \%$, and $10 \%$, respectively. 
Table 4: Chinese Import Competition and Formal Sector Employment: Worker Level Analysis

Indicator for Employment in Formal Enterprise

(1)

$(2)$

$(3)$

$(4)$

$(5)$

(6)

\begin{tabular}{lcccccc} 
Chinese Import Competition (IMP) & $\begin{array}{c}0.568^{* * *} \\
(0.168)\end{array}$ & $\begin{array}{c}0.567^{* * *} \\
(0.151)\end{array}$ & $\begin{array}{c}0.522^{* * *} \\
(0.163)\end{array}$ & $\begin{array}{c}0.538^{* * *} \\
(0.196)\end{array}$ & $\begin{array}{c}0.512^{* * *} \\
(0.178)\end{array}$ & $\begin{array}{c}0.466^{* *} \\
(0.190)\end{array}$ \\
\hline Estimation Method & OLS & OLS & OLS & IV & IV & IV \\
First-stage F-statistic & - & - & - & 774.13 & 776.81 & 802.64 \\
Worker Characteristics & No & Yes & Yes & No & Yes & Yes \\
Worker Characteristics $\times$ Year=2004 & No & No & Yes & No & No & Yes \\
Alternative Trade Channels & Yes & Yes & Yes & Yes & Yes & Yes \\
3-digit-industry $\times$ Year FE & Yes & Yes & Yes & Yes & Yes & Yes \\
State $\times$ Year FE & Yes & Yes & Yes & Yes & Yes & Yes \\
State $\times$ Industry FE & Yes & Yes & Yes & Yes & Yes & Yes \\
Observations & 36,017 & 36,017 & 36,010 & 36,017 & 36,017 & 36,010 \\
\hline
\end{tabular}

Note: The NSSO employment-unemployment survey for the years 1999-2000 and 2004-2005 are used for analysis. Worker characteristics include age and its squared, marital status indicator, female indicator, education status, rural residence indicator, religious minority status indicator, and disadvantaged social category indicator. In the IV specifications, Chinese imports to India is instrumented with Chinese imports into a set of 10 Latin American countries. Alternative trade channels include output and input tariffs, access to Chinese inputs, import penetration from high income countries and low and middle income countries separately, Chinese import share in high income countries, Chinese import share in low and middle income countries, and India's export share in the total exports to the set of Latin American countries used to create the instrument. All regressions are weighted using sample weights from the NSSO employment-unemployment survey. Robust standard errors clustered at the 4-digit industry level in parentheses; $* * *$ - statistical significance at $1 \%$; **- statistical significance at $5 \%$; * statistical significance at $10 \%$. 


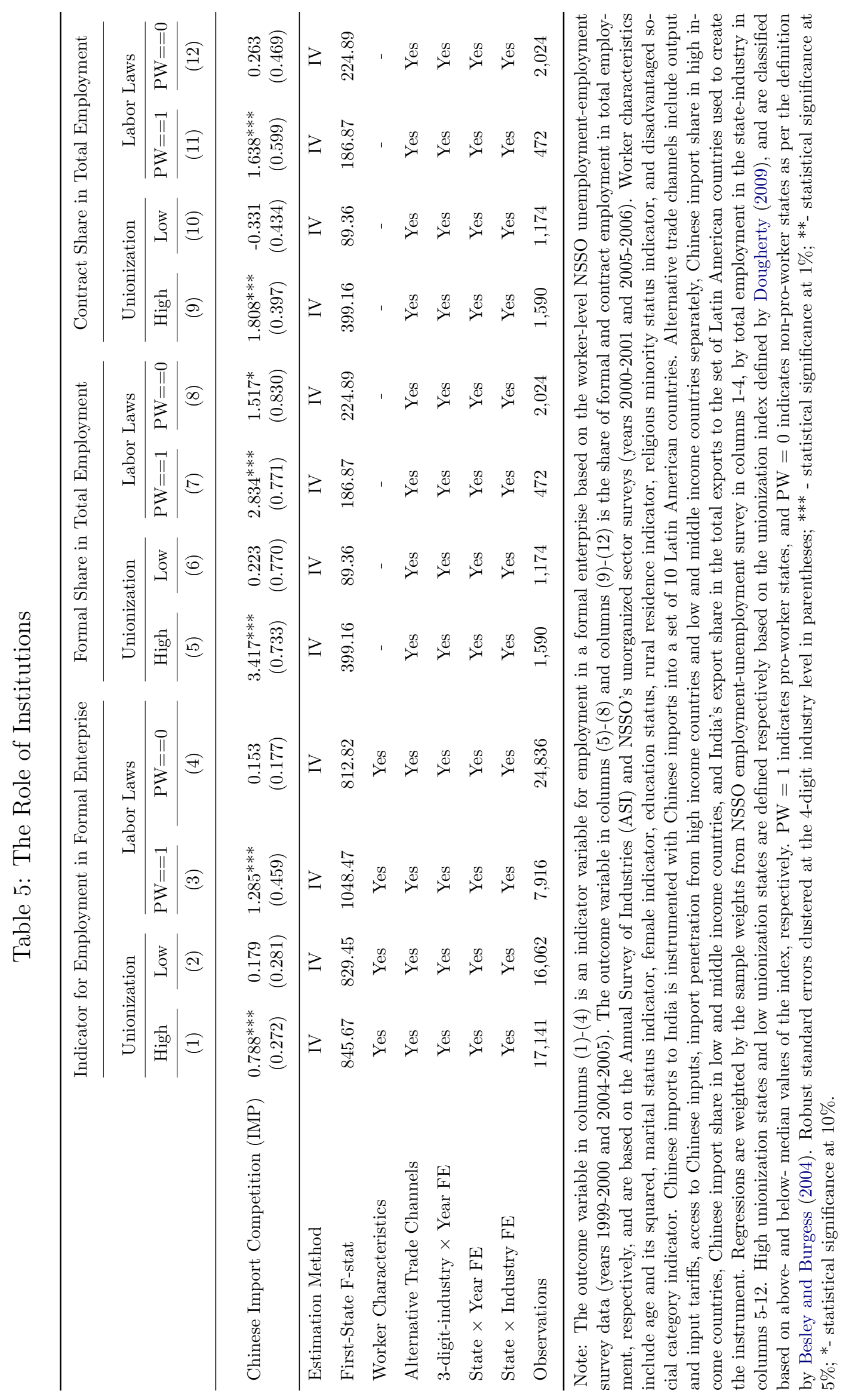




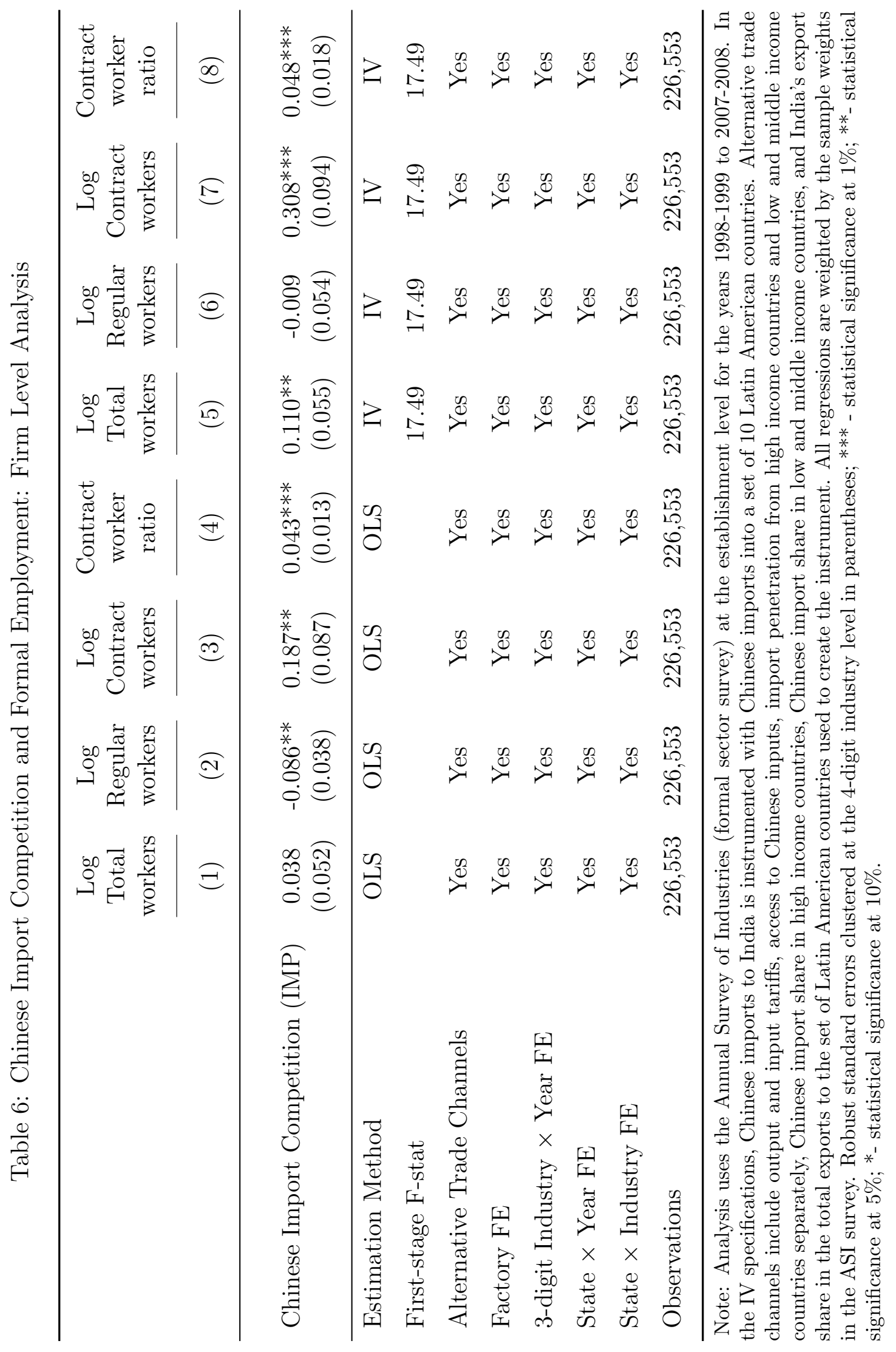


Table 7: Chinese Import Competition and Employment: Heterogeneity based on initial Total Factor Productivity (TFP)

\begin{tabular}{|c|c|c|c|c|}
\hline & $\begin{array}{c}\text { Log } \\
\text { Total } \\
\text { workers }\end{array}$ & $\begin{array}{c}\text { Log } \\
\text { Regular } \\
\text { workers }\end{array}$ & $\begin{array}{c}\text { Log } \\
\text { Contract } \\
\text { workers }\end{array}$ & $\begin{array}{c}\text { Contract } \\
\text { worker } \\
\text { ratio }\end{array}$ \\
\hline & (1) & $(2)$ & $(3)$ & $(4)$ \\
\hline Chinese Import Competition (IMP) & $\begin{array}{c}-0.0609 \\
(0.0975)\end{array}$ & $\begin{array}{l}0.0514 \\
(0.108)\end{array}$ & $\begin{array}{c}-0.127 \\
(0.104)\end{array}$ & $\begin{array}{c}-0.0363 \\
(0.0271)\end{array}$ \\
\hline $\mathrm{IMP} \times Q r_{2}$ & $\begin{array}{c}0.122 \\
(0.104)\end{array}$ & $\begin{array}{r}-0.0407 \\
(0.112)\end{array}$ & $\begin{array}{c}0.269^{* *} \\
(0.133)\end{array}$ & $\begin{array}{c}0.0531^{*} \\
(0.0295)\end{array}$ \\
\hline $\mathrm{IMP} \times Q r_{3}$ & $\begin{array}{c}0.390^{* *} \\
(0.171)\end{array}$ & $\begin{array}{l}0.0469 \\
(0.201)\end{array}$ & $\begin{array}{c}0.577^{* * *} \\
(0.198)\end{array}$ & $\begin{array}{c}0.124^{* *} \\
(0.0512)\end{array}$ \\
\hline $\mathrm{IMP} \times Q r_{4}$ & $\begin{array}{c}0.492^{* * *} \\
(0.158)\end{array}$ & $\begin{array}{c}0.105 \\
(0.128)\end{array}$ & $\begin{array}{c}0.505^{* *} \\
(0.222)\end{array}$ & $\begin{array}{c}0.118^{* * *} \\
(0.0369)\end{array}$ \\
\hline Estimation Method & IV & IV & IV & IV \\
\hline First-stage F-stat $(I M P)$ & 75.05 & 73.92 & 74.88 & 73.57 \\
\hline First-stage F-stat $\left(I M P \times Q_{r 2}\right)$ & 42.66 & 41.12 & 39.66 & 41.74 \\
\hline First-stage F-stat $\left(I M P \times Q_{r 3}\right)$ & 52.42 & 47.15 & 42.14 & 38.32 \\
\hline First-stage F-stat $\left(I M P \times Q_{r 4}\right)$ & 33.09 & 32.79 & 33.27 & 33.26 \\
\hline Alternative Trade Channels & Yes & Yes & Yes & Yes \\
\hline Factory FE & Yes & Yes & Yes & Yes \\
\hline 3-digit Industry $\times$ Year FE & Yes & Yes & Yes & Yes \\
\hline State $\times$ Year FE & Yes & Yes & Yes & Yes \\
\hline State $\times$ Industry FE & Yes & Yes & Yes & Yes \\
\hline Observations & 196,956 & 196,956 & 196,956 & 196,956 \\
\hline
\end{tabular}

Note: Analysis uses the ASI data (formal sector firms) at the establishment level for the years 1998-1999 to 2007-2008. $Q r_{i}$ is an indicator variable which is equal to 1 if a firm belongs to the $i^{\text {th }}$ quartile of the productivity distribution (total) when it first enters our sample. We calculate TFP using the methodology of Ackerberg et al. (2015). To obtain values in real terms, we use output and input deflators from Allcott et al. (2016) and capital deflators from Reserve Bank of India (RBI) publications. Chinese imports to India, and its interaction with the quartile indicator variables are instrumented with Chinese imports into a set of 10 Latin American countries and their corresponding interaction with quartiles. Alternative trade channels include output and input tariffs, access to Chinese inputs, import penetration from high income countries and low and middle income countries separately, Chinese import share in high income countries, Chinese import share in low and middle income countries, and India's export share in the total exports to the set of Latin American countries used to create the instrument. All regressions are weighted by the sample weights in the ASI survey. Robust standard errors clustered at the 4-digit industry level in parentheses; $* * *$ - statistical significance at $1 \%$; **- statistical significance at $5 \% ; *_{\text {- }}$ statistical significance at $10 \%$. 
Table 8: Productivity Gap Between Formal and Informal Enterprises

\begin{tabular}{|c|c|c|}
\hline & $\begin{array}{c}\text { Revenue } \\
\text { Productivity Gap }\end{array}$ & $\begin{array}{l}\text { Wage } \\
\text { Gap }\end{array}$ \\
\hline & $(1)$ & $(2)$ \\
\hline A. Unadjusted & 10.95 & 3.12 \\
\hline \multicolumn{3}{|l|}{ B. Adjusted for: } \\
\hline (1) Hours Worked & 5.09 & 1.45 \\
\hline$(2)=(1)+$ Human Capital Differences & 3.77 & 1.07 \\
\hline$(3)=(2)+$ Differences in Prices & 2.18 & - \\
\hline$(4)=(3)+$ Measurement Error in Revenue & 1.53 & - \\
\hline$(5)=(4)+$ Difference in Output Elasticity & 1.24 & - \\
\hline \multicolumn{3}{|l|}{ Productivity Gains(\%): } \\
\hline Using Estimates in (2) & 5.13 & 0.3 \\
\hline Using Estimates in (3) & 3.19 & \\
\hline Using Estimates in (5) & 0.89 & \\
\hline
\end{tabular}

Note: Column 1 reports the labor productivity gap between formal and informal enterprises, where labor productivity is measured by average revenue per worker. Column 2 reports the labor productivity gap between formal and informal enterprises, where labor productivity is measured by earnings per worker. These calculations use data from the Annual Survey of Industries for the formal sector, and data from the NSSO's unorganized enterprises survey for the informal sector for the years 2000-2001 and 2005-2006. 


\section{Appendix A}

Imported inputs is defined as follows:

$$
I N P_{j t}^{C h i n a}=\sum_{s} \alpha_{j s} \cdot I M P_{s t}^{C h i n a}
$$

where $\alpha_{j s}$ is the share of input $s$ in the total output for industry $j$, and $I M P_{s t}^{C h i n a}$ is the import penetration ratio for input $s$. To obtain a measure of imported inputs from China in each industry, we used the input-output (IO) mapping table for India for the year 1993-94 (Ministry of Statistics and Programme Implementation, 2000). Input $s$ in equation (10) refers to a sector in this IO table. This input-output table is an $n \times n$ matrix of IO sectors. For each IO sector $s$ in each row, the columns give the share of other IO sectors which are used as inputs, which are represented by $\alpha_{j s}$ in equation (10). Using $I M P_{j t}^{C h i n a}$ for industry $j$ from (1), we use a simple mapping between industries $(j)$ and the IO sectors $(s)$, to obtain a measure of $I M P_{s t}^{C h i n a}$ for each IO sector $s$. This then feeds into equation (10). We also instrument for access to imported inputs from China, $I N P_{j t}^{C h i n a}$, which is given by:

$$
I V I N P_{j t}^{\text {China }}=\sum_{s} \alpha_{j s} \cdot I V_{s t}^{\text {China }}
$$

where the instrument is the weighted average of the instrument for import penetration ratio calculated for the input sector $s$ similar to (5) above. $I V_{s t}^{C h i n a}$ is the instrumental variable for import penetration ratio defined in equation 2 .

We proxy for Chinese import competition in foreign markets by Chinese import share in these markets given by the following equation:

$$
I S_{j t}^{C h i n a, F}=\frac{M_{j t}^{C h i n a, F}}{M_{j t}^{W o r l d, F}}
$$

where $I S_{j t}^{C h i n a, F}, M_{j t}^{C h i n a, F}$, and $M_{j t}^{W o r l d, F}$ are Chinese import share in the foreign market, imports from China to the foreign market, and total imports to the foreign markets in industry $j$ and time $t$ respectively. Foreign market, $F$, is either the set of low and middle income economies except China or the set of high income countries.

We compute the import penetration from other countries into India using equation (1), where we replace Chinese imports with imports from the set of low and middle income countries or the 
high income countries. Finally, we use Indian exports to the set of IV countries as a share of total exports from India as a control variable. 
Appendix B 
Table B1: Chinese Import Competition and Employment: State-Year Level Analysis, Robustness Checks

Share in

total employment

(1)

(2)

\begin{tabular}{lcc} 
Chinese Import Competition (IMP) & $\begin{array}{c}1.346^{* * *} \\
(0.283)\end{array}$ & $\begin{array}{c}1.346^{* *} \\
(0.662)\end{array}$ \\
\hline IV First-stage F-stat & 259.24 & 248.05 \\
Cluster at NIC3 Industry & Yes & No \\
Control for Dereservation & No & Yes \\
Alternative Trade Channels & Yes & Yes \\
State $\times$ Industry FE & Yes & Yes \\
3-digit-industry $\times$ Year FE & Yes & Yes \\
State $\times$ Year FE & Yes & Yes \\
Observations & 3,702 & 3,702 \\
\hline
\end{tabular}

Note: Analysis is conducted at the 4-digit state-industryyear level. We use Annual Survey of Industries (ASI) to measure formal employment and the NSSO's unorganized sector surveys to measure informal employment. We use surveys conducted in 2000-2001 and 2005-2006. In the IV specifications, Chinese imports to India is instrumented with Chinese imports into a set of 10 Latin American countries. Alternative trade channels include output and input tariffs, access to Chinese inputs, import penetration from high income countries and low and middle income countries separately, Chinese import share in high income countries, Chinese import share in low and middle income countries, and India's export share in the total exports to the set of Latin American countries used to create the instrument. Regressions are weighted by total employment in the state-industry in the year 20002001. Robust standard errors clustered at the 4-digit industry level in parentheses. $* * *, * *, *$ is statistical significance at $1 \%, 5 \%$, and $10 \%$, respectively. 
Table B2: Chinese Import Competition, Employment, and Employment Shares : Industry Level Analysis

\begin{tabular}{|c|c|c|c|c|c|c|}
\hline & \multirow{4}{*}{$\begin{array}{c}\text { Share in } \\
\text { total employment } \\
\text { Formal } \\
(1)\end{array}$} & \multicolumn{5}{|c|}{ Log Employment } \\
\hline & & \multirow{3}{*}{$\begin{array}{c}\text { Total } \\
(2)\end{array}$} & \multirow{3}{*}{$\begin{array}{c}\text { Informal } \\
\\
(3)\end{array}$} & \multicolumn{3}{|c|}{ Formal } \\
\hline & & & & Total & Regular & Contract \\
\hline & & & & $(4)$ & $(5)$ & $(6)$ \\
\hline \multicolumn{7}{|l|}{ Panel A: OLS } \\
\hline Chinese Import Competition (IMP) & $\begin{array}{c}3.074^{* * *} \\
(0.741)\end{array}$ & $\begin{array}{l}-4.839 \\
(3.781)\end{array}$ & $\begin{array}{c}-13.34^{* *} \\
(5.183)\end{array}$ & $\begin{array}{c}3.858^{*} \\
(2.056)\end{array}$ & $\begin{array}{c}2.201 \\
(1.889)\end{array}$ & $\begin{array}{c}8.091^{* * *} \\
(2.948)\end{array}$ \\
\hline \multicolumn{7}{|l|}{ Panel B: IV } \\
\hline Chinese Import Competition (IMP) & $\begin{array}{c}3.174^{* * *} \\
(0.757)\end{array}$ & $\begin{array}{l}-5.086 \\
(4.076)\end{array}$ & $\begin{array}{c}-13.94^{* *} \\
(5.463)\end{array}$ & $\begin{array}{c}3.955 \\
(2.410)\end{array}$ & $\begin{array}{c}2.252 \\
(2.042)\end{array}$ & $\begin{array}{c}8.183^{* *} \\
(3.885)\end{array}$ \\
\hline First-stage F-stat & 177.42 & 177.42 & 259.12 & 144.97 & 144.97 & 144.97 \\
\hline Alternative Trade Channels & Yes & Yes & Yes & Yes & Yes & Yes \\
\hline Industry FE & Yes & Yes & Yes & Yes & Yes & Yes \\
\hline 3-digit-industry $\times$ Year FE & Yes & Yes & Yes & Yes & Yes & Yes \\
\hline Observations & 110 & 110 & 110 & 110 & 110 & 110 \\
\hline
\end{tabular}

Note: Analysis is conducted at the 4-digit industry-year level. We use Annual Survey of Industries (ASI) to measure formal employment, and the NSSO's unorganized sector surveys to measure informal employment. We use surveys conducted in 2000-2001 and 2005-2006. Chinese imports to India is instrumented with Chinese imports into a set of 10 Latin American countries. Alternative trade channels include output and input tariffs, access to Chinese inputs, import penetration from high income countries and low and middle income countries separately, Chinese import share in high income countries, Chinese import share in low and middle income countries, and India's export share in the total exports to the set of Latin American countries used to create the instrument. All regressions are weighted by the industry employment in the year 2000-2001. Robust standard errors clustered at the 4-digit industry level in parentheses; $* * *$ - statistical significance at $1 \%$; **- statistical significance

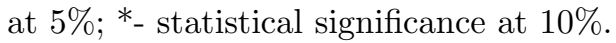


Table B3: Chinese Import Competition and Reallocation of Output

$\begin{array}{lcll}\log (\text { Number of Factories }) & & \log (\text { Sales }) \\ & \text { Formal } & \text { Informal } & \text { Formal }\end{array}$

(1)

\begin{tabular}{lcccc} 
Chinese Import Competition (IMP) & $\begin{array}{c}-14.59^{* *} \\
(7.087)\end{array}$ & $\begin{array}{c}3.974^{* *} \\
(1.693)\end{array}$ & $\begin{array}{c}-12.97^{*} \\
(6.619)\end{array}$ & $\begin{array}{c}-0.118 \\
(1.796)\end{array}$ \\
\hline IV First-stage F-stat & 427.07 & 223 & 408.34 & 222.97 \\
Alternative Trade Channels & Yes & Yes & Yes & Yes \\
State $\times$ Industry FE & Yes & Yes & Yes & Yes \\
3-digit-industry $\times$ Year FE & Yes & Yes & Yes & Yes \\
State $\times$ Year FE & Yes & Yes & Yes & Yes \\
Observations & 2,766 & 2,894 & 2,596 & 2,880 \\
\hline
\end{tabular}

Note: Analysis is conducted at the 4-digit state-industry-year level. We use Annual Survey of Industries (ASI) to measure formal employment and the NSSO's unorganized sector surveys to measure informal employment. We use surveys conducted in 2000-2001 and 2005-2006. In the IV specifications, Chinese imports to India is instrumented with Chinese imports into a set of 10 Latin American countries. Alternative trade channels include output and input tariffs, access to Chinese inputs, import penetration from high income countries and low and middle income countries separately, Chinese import share in high income countries, Chinese import share in low and middle income countries, and India's export share in the total exports to the set of Latin American countries used to create the instrument. Regressions are weighted by total employment in the stateindustry in the year 2000-2001. Robust standard errors clustered at the 4-digit industry level in parentheses. ${ }^{* *}, * *, *$ is statistical significance at $1 \%, 5 \%$, and $10 \%$, respectively. 
Table B4: Chinese Import Competition and Employment: District Level

\begin{tabular}{lccccc}
\hline & \multicolumn{4}{c}{$\log ($ Employment $)$} \\
\cline { 2 - 3 } & Overall & Manufacturing & Services & Agriculture \\
\cline { 2 - 3 } \cline { 5 - 6 } & $(1)$ & & $(2)$ & & $(3)$ \\
\hline Chinese Import Competition (IMP) & -11.92 & $-39.73^{* *}$ & -13.95 & 11.05 \\
& $(18.14)$ & $(19.24)$ & & $(20.04)$ & $(23.41)$ \\
\hline Estimation Method & IV & IV & IV & IV \\
First-stage F-stat & - & & & - \\
Alternative Trade Channels & Yes & Yes & Yes & Yes \\
District FE & Yes & Yes & Yes & Yes \\
Year FE & Yes & Yes & Yes & Yes \\
Observations & 932 & 924 & 896 & 930 \\
\hline
\end{tabular}

Note: The NSSO employment-unemployment survey for the years 1999-2000 and 2004-2005 are used for analysis. Chinese imports to India is instrumented with Chinese imports into a set of 10 Latin American countries. Alternative trade channels include import penetration from high income countries and low and middle income countries separately. All regressions are weighted by the initial employment share of the district in overall employment. Robust standard errors clustered at the district level in parentheses; $* * *$ - statistical significance at $1 \%$; **-statistical significance at $5 \%$; *- statistical significance at $10 \%$. 
Table B5: Chinese Import Competition and Formal Sector Employment: Worker Level Analysis, Robustness Checks

Indicator for Employment in Formal Enterprise

(1) $0.464 * * *$

$(0.170)$

$(3)$

\author{
$(2)$
}

\begin{tabular}{lcccc} 
Chinese Import Competition (IMP) & $\begin{array}{c}0.464^{* * *} \\
(0.170)\end{array}$ & $\begin{array}{c}0.466^{* *} \\
(0.190)\end{array}$ & $\begin{array}{c}0.466^{* *} \\
(0.190)\end{array}$ & $\begin{array}{c}0.395^{* *} \\
(0.196)\end{array}$ \\
\hline Estimation Method & IV & IV & IV & IV \\
Cluster at NIC3 Industry & Yes & No & No & No \\
Control for Dereservation & No & Yes & No & No \\
Worker Characteristics & Yes & Yes & Yes & Yes \\
Worker Characteristics $\times$ Year=2004 & Yes & Yes & Yes & Yes \\
Alternative Trade Channels & Yes & Yes & Yes & Yes \\
3-digit-industry $\times$ Year FE & Yes & Yes & Yes & Yes \\
State $\times$ Year FE & Yes & Yes & Yes & Yes \\
State $\times$ Industry FE & Yes & Yes & Yes & Yes \\
Observations & 36,010 & 36,010 & 36,010 & 35,583 \\
\hline
\end{tabular}

Note: The NSSO employment-unemployment survey for the years 1999-2000 and 2004-2005 are used for analysis. Worker characteristics include age and its squared, marital status indicator, female indicator, education status, rural residence indicator, religious minority status indicator, and disadvantaged social category indicator. In the IV specifications, Chinese imports to India is instrumented with Chinese imports into a set of 10 Latin American countries. Alternative trade channels include output and input tariffs, access to Chinese inputs, import penetration from high income countries and low and middle income countries separately, Chinese import share in high income countries, Chinese import share in low and middle income countries, and India's export share in the total exports to the set of Latin American countries used to create the instrument. Column 3 defines informal workers using the size threshold in the Factories Act, 1948. Column 4 drops all observations where workers report working for a firm that is an informal firm based on the size thresholds in the Factories Act but are registered firms. All regressions are weighted using sample weights from the NSSO employment-unemployment survey. Robust standard errors clustered at the 4-digit industry level in parentheses; *** - statistical significance at 1\%; **- statistical significance at 5\%; *- statistical significance at $10 \%$. 


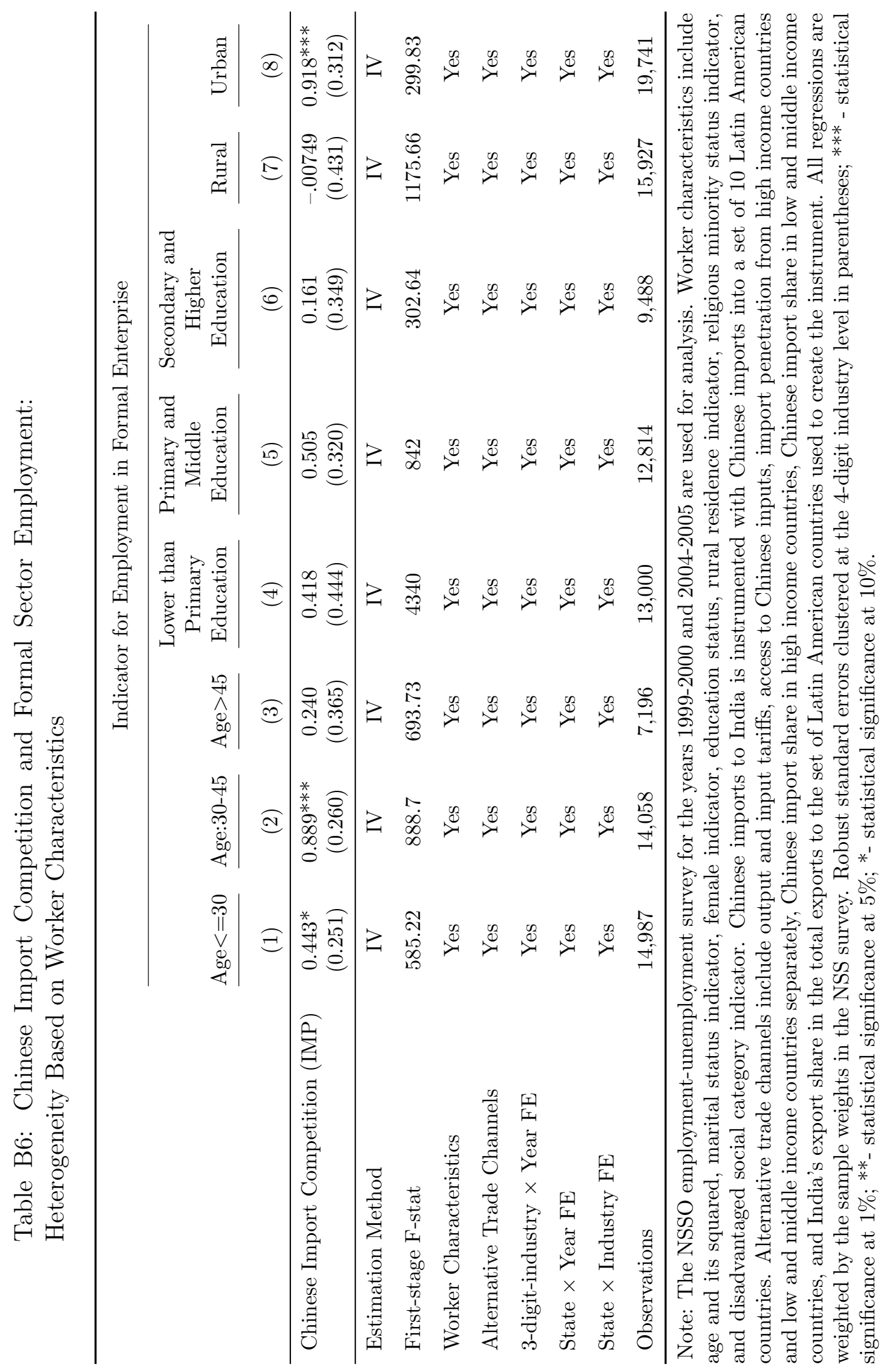




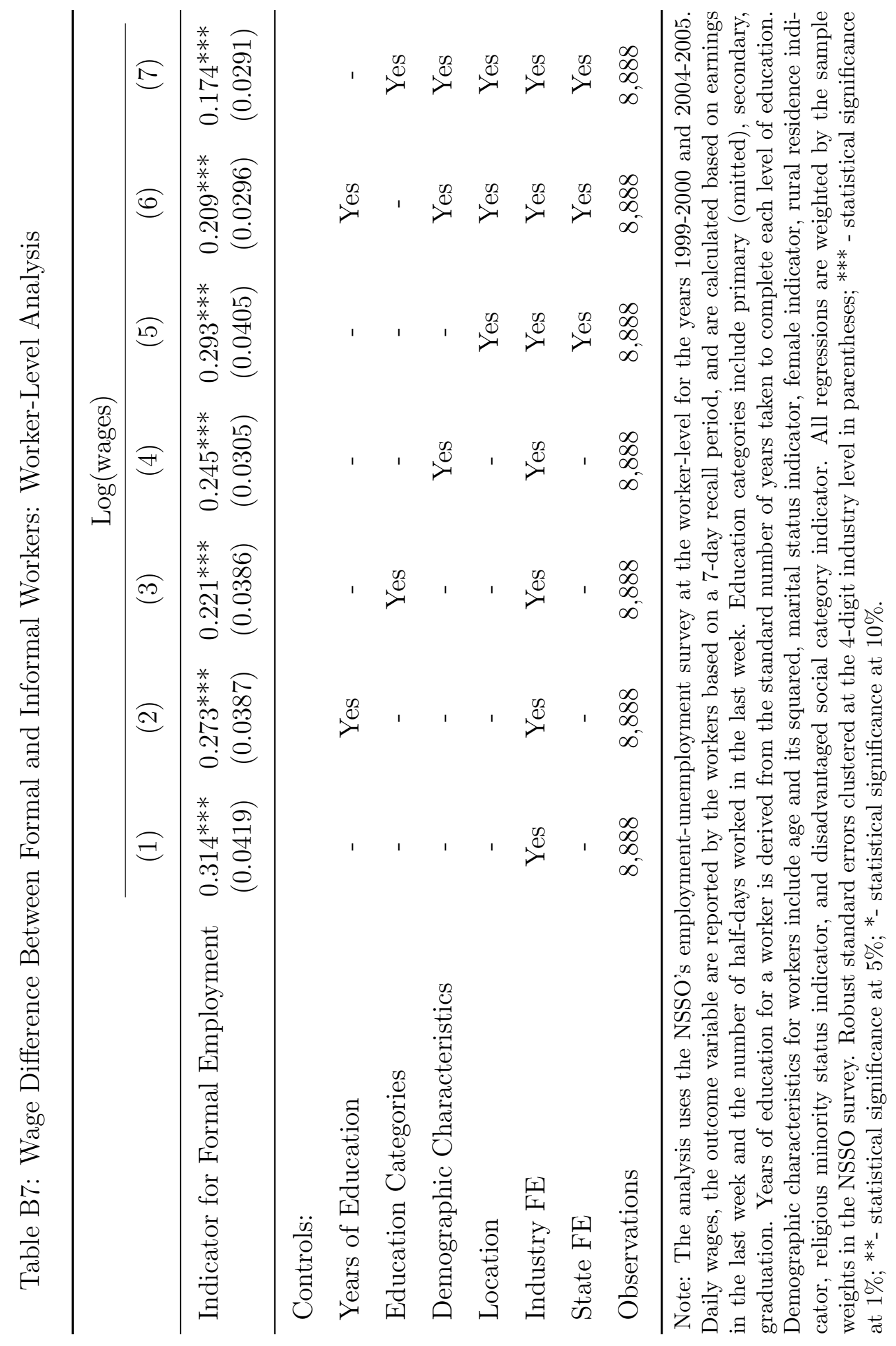




\section{Appendix C: Labor Productivity Gap}

\section{C0.1 Calculation of Unadjusted Productivity Gap}

Using Equation 8 in the main text, we calculate labor productivity gap using both revenue per worker as well as wages using data from the ASI-NSS firm level surveys. For calculating revenue per worker, we aggregate revenue and employment for all firms in each sector and take the ratio. The productivity gap is then given by the ratio of labor productivity between the formal and informal sector. We perform similar calculations to get the wage gap. We sum up the total compensation paid to employees as well the number of employees for each sector and take the ratio to arrive at the average wage per worker in a sector. We take the ratio of the average wage for the formal and informal sector to get the wage gap across the two sectors.

\section{C0.2 Adjusting for Differences in Hours Worked}

A major concern with the observed labor productivity gap is that it may be driven by differences in average number of hours worked across the two sectors. If informal workers on average work fewer hours we would overestimate the labor productivity gap. To make progress on this issue, we indirectly infer the total number of hours worked for workers in each sector. For the informal sector, we utilize availability of information on average number of hours worked per day and the number of months in operation for the enterprise. However this information is only available for the 2005 round of the NSS survey which forces us to use the ASI-NSS 2005 round to measure differences in hours worked across the two sectors. We assume that the average number of hours worked across the two sectors does not change significantly across the two sectors between the two rounds. Indeed, in the case of Vietnam, McCaig and Pavcnik (2018) find that average number of hours worked do not vary much across two separate surveys of the informal and formal sector firms.

We calculate the total number of hours worked by all employees for each firm as:

$$
H_{i}=30 \times n \times h_{i}
$$


where $n$ is number of months in operation, and $h_{i}$ is average number of hours worked as reported by the firm. For the formal sector, we utilize data on number of mandays for each firm. We calculate the total number of hours worked for the formal sector firm as $H_{f}=8 \times$ mandays, assuming a 8 hour working shift for the formal firms. We sum $H_{i}$ and $H_{f}$ for all firms to arrive at the total number of hours worked for the informal and formal sector, respectively. Next, we adjust the raw productivity and wage gap by comparing the ratio of employees to the ratio of hours worked across the two sectors. Our estimates provide an adjustment factor of 2.15 suggesting that differences in hours worked account for a significant portion of the large unadjusted productivity gap.

\section{C0.3 Adjusting for Difference in Human Capital}

There may be significant differences in the human capital for workers in the two sectors that may lead to overestimation of the productivity gap. To account for this heterogeneity, we follow Gollin et al. (2014), who adjust for differences in average years of education across the agriculture and nonagriculture sectors, and compute average human capital in a sector as $e^{\text {red }_{s}}$ where $r$ is the rate of return on each year of education and $e d_{s}$ is the average years of education in each sector $s$. The EUS worker level survey provides details about the education level of each worker but does not report the years of education. We infer the years of education for each worker based on the level of education qualification using the standard number of years required to complete that level of education in the Indian education system. We assign 5 years to primary education, 8 years to middle, 10 years to secondary, 12 years to higher secondary, and 15 years to undergraduate and above. We assume a rate of return of $10 \%$ for each year of education following Gollin et al. (2014). Using the above approach, we estimate that the average human capital in formal sector is 1.35 times that in the informal sector.

\section{C0.4 Adjusting for Difference in Prices}

The labor productivity gap, as measured by revenue per unit labor, may reflect the effect of differences in demand shocks and markup in addition to the true labor productivity gap. The ASI-NSS data is 
unique in that we observe sales and quantity produced for all products (upto 10 products) produced by each firm. We restrict our sample to firms that produce 10 or fewer products. These surveys assign each product produced by the firm to a 5 digit ASICC product code. Our approach for correcting for price differences involves comparing average prices across the two sectors. We start by calculating the firm level prices (unit values) by dividing the firm product sales by quantity produced. Then we calculate the firm level prices as the sales share weighted sum of firm product level prices. Next, we calculate the real sales of a firm as the nominal sales deflated by the firm level prices calculated above. We compare the real sales per worker gap between the formal and informal sectors to the nominal sales per worker gap to arrive at a correction factor of 1.73 . We adjust the labor productivity gap by this factor and report the adjusted gap in row (3) of Table 8. The labor productivity gap in column 1 drops from 3.77 to 2.18 due to this adjustment, suggesting that there are significant differences in average firm level prices across the two sectors. Ignoring these price differences would greatly overestimate the labor productivity gap between the two sectors. 